\title{
Influence of immunoglobulin heavy- and light-chain expression on B-cell differentiation
}

\author{
Faith Young, ${ }^{1}$ Blair Ardman, ${ }^{2}$ Yoichi Shinkai, ${ }^{1}$ Rusty Lansford, ${ }^{1}$ T. Keith Blackwell, ${ }^{3}$ \\ Monica Mendelsohn, ${ }^{4}$ Antonius Rolink, ${ }^{5}$ Fritz Melchers, ${ }^{5}$ and Frederick W. Alt ${ }^{1,3,6}$ \\ ${ }^{1}$ Howard Hughes Medical Institute and the Department of Genetics and Pediatrics, The Children's Hospital, Boston, \\ Massachusetts 02115 USA; $^{2}$ Department of Medicine, Division of Hematology and Oncology, Tufts/New England Medical \\ Center Hospital, Boston, Massachusetts 02111 USA; $^{3}$ Center for Blood Research, Harvard Medical School, Boston, \\ Massachusetts 02115 USA; ${ }^{4}$ Columbia University, New York, New York 10032 USA; ${ }^{5}$ Basel Institute for Immunology, \\ Basel, Switzerland
}

To study the influence of immunoglobulin heavy-chain (HC) and light-chain (LC) expression in promoting B-cell differentiation, we have introduced functional immunoglobulin $\mathrm{HC}$ and/or LC transgenes into the recombinase activating gene-2-deficient background (RAG-2 ${ }^{-1-}$ ). RAG-2 $2^{-1}$ mice do not undergo endogenous $V(D) J$ rearrangement events and, therefore, are blocked in B- and T-cell development at the early pro-B- and pro-T-cell stages. Introduction of immunoglobulin HC transgenes into the RAG-2 ${ }^{-1}$ background promotes the development of a B-lineage cell population that phenotypically has the characteristics of pre-B cells. We have shown further that this population has altered growth characteristics as measured by interleukin-7 responsiveness in culture. Bone marrow cells from immunoglobulin HC transgenic RAG-2 ${ }^{-1-}$ mice have up-regulated expression of germ-line $\kappa$ LC gene transcripts and down-regulated expression of $\lambda_{5}$ surrogate LCs (SLCs). Although $\mu \mathrm{HC} / \mathrm{SLC}$ complexes are detectable intracellularly in HC/RAG-2 ${ }^{-1}$ pre-B-cell populations, HC expression is not readily detectable on the surface of these cells. $\lambda$ LC RAG- ${ }^{-1}$ mice had a bone marrow B-lineage cell phenotype indistinguishable from that of RAG-2 ${ }^{-1-}$ littermates, indicating that LC expression by itself has no influence on pro-B cell differentiation. Strikingly, simultaneous introduction of $\mu \mathrm{HC}$ and $\lambda$ LC transgenes into RAG-2 $2^{-/}$mice led to the generation of a substantial population of "monoclonal" peripheral B-cells that were functional with regard to immunoglobulin secretion, indicating that $T$ cells or diverse immunoglobulin repertoires are not necessary for peripheral B-cell development.

[Key Words: RAG-2; B-cell development; immunoglobulin transgenes; pre-B-cells; surrogate light chains]

Received February 25, 1994; revised version accepted March 18, 1994.

B-lymphocyte differentiation occurs in the bone marrow of adult mammals and has been subdivided into a series of steps based on the rearrangement status of immunoglobulin $(\mathrm{HC})$ heavy-chain and $(\mathrm{LC})$ light-chain genes and the expression of characteristic sets of cell-surface antigens (Coffman and Weissman 1983; Hardy et al. 1991; Li et al. 1993; for review, see Rolink and Melchers 1991, 1993). Most developing precursor B cells first assemble immunoglobulin $\mathrm{HC}$ variable region genes from component $V_{\mathrm{H}} D$, and $J_{\mathrm{H}}$ segments which permits expression of a $\mu \mathrm{HC}$; subsequently, immunoglobulin LC variable region genes are assembled from component $V_{\mathrm{L}}$ and $J_{L}$ segments, followed by expression of $\kappa$ or $\lambda$ LCs /for review, see Alt et al. 1987; Rolink and Melchers 1991). Immunoglobulin $\mathrm{HC}$ and $\mathrm{LC}$ associate to form complete immunoglobulin molecules that are expressed as an antigen receptor on the surface of immature B lymphocytes (for review, see Alt et al. 1987; Rolink and Melchers

${ }^{6}$ Corresponding author.
1991|. Differentiating precursor B-cell subsets have been characterized further by differences in cell size and turnover as well as by expression of various surface markers (Hardy et al. 1991; for review, see Osmond 1990; Rolink and Melchers 1993|. These markers define a spectrum of stages including the most immature pro-B cells, which are large, rapidly proliferating, $\mathrm{CD} 43(\mathrm{~S} 7)^{+}, \mathrm{c}^{-} \mathrm{kit}^{+}$, $\mathrm{B} 220(\mathrm{CD} 45 \mathrm{R})^{+}, \mathrm{Ig}^{-}$cells in the process of assembling immunoglobulin $\mathrm{HC}$ variable region genes to the more mature pre-B-cells, which are small, relatively quiescent, $\mathrm{CD}^{2} 3^{-}, \mathrm{B} 220^{+}$, cytoplasmic $\mu^{+}$cells in the process of assembling and expressing immunoglobulin LC genes (for review, see Melchers et al. 1993).

Expression of the membrane-bound form of the $\mu \mathrm{HC}$ $(\mu \mathrm{m})$ appears to be a critical signal for regulatory events associated with control of immunoglobulin HC gene rearrangement and the progression of pro- $\mathrm{B}$ cells from the large $\mathrm{CD}_{4} 3^{+}$stage to the small $\mathrm{CD} 43^{-}$stage in which immunoglobulin LC genes are rearranged efficiently (Kitamura et al. 1991, 1992). In pre-B cell lines and in normal pre-B cells, the $\mu \mathrm{m}$ protein has been found to be 
associated with surrogate light-chains (SLCs; $\lambda_{5}$ and $\mathrm{V}_{\text {preB }}$ ); this complex has been detected on the surface of pro- and/or pre-B cells /Karasuyama et al. 1990, 1993; Cherayil and Pillai 1991; Misener et al. 1991; Nishimoto et al. 1991; Kerr et al. 1989; Lassoued et al. 1993; for review, see Melchers et al. 1993.) These findings have led to the suggestion that expression of this complex may be involved in some way with generating the developmental signals ascribed to the expression of the $\mu \mathrm{m}$ protein. In support of this notion, B-cell-differentiation is impeded at the large, $\mathrm{CD}_{4} 3^{+}$stage in mice that harbor homozygous mutations that inactivate expression of either $\mu \mathrm{m}$ or $\lambda_{5}$ proteins (Kitamura et al. 1991, 1992). Despite the block in B-cell development, $\mathrm{k}$ rearrangements were detected in purified $\mathrm{CD} 43^{+}$pro-B cells from HC-deficient mice (Chen et al. 1993; Ehlich et al. 1993) and the $\lambda_{5}$-deficient mice accumulated normal B cells, albeit inefficiently (Kitamura et al. 1992; Rolink et al. 1993). These results demonstrated that LC gene rearrangement was possible without expression of $\mu \mathrm{m}$ protein or the $\mu$-surrogate light-chain (SLC) complex and led to the proposal of an alternate pathway of B-cell development in which LC gene rearrangement precedes that of $\mathrm{HC}$ (Ehlich et al. 1993).

Surface $\mathrm{Ig}^{+} \mathrm{B}$ cells migrate from the bone marrow to populate lymphoid organs in the periphery where clonal expansion and further differentiation can occur during the humoral immune response (for review, see Rajewsky 1992; Clark and Ledbetter 1994). Studies of mice homozygous for the severe combined immune deficiency mutation (SCID mice), which generally lack mature B and $T$ cells, are relevant to these issues. SCID mice have a block in B-cell development at the $\mathrm{CD} 43^{+}, \mathrm{B} 220^{+}$ stage attributable to an impairment in the $V(D) I$ recombination process (Hendrickson et al. 1990; Lieber et al. 1988; Malynn et al. 1988; Blackwell et al. 1989; Reichman-Fried et al. 1990, 1993; Biedermann et al. 1991; for review, see Bosma and Carroll 1991). However, whereas introduction of a functionally assembled immunoglobulin HC gene into the SCID background generated a population of $\mathrm{B} 220^{+}, \mathrm{CD} 43^{-}$pre-B cells (Reichman-Fried et al. 1993), introduction of HC plus LC transgenes into the homozygous SCID background has not led reproducibly to the development of significant numbers of B lymphocytes in primary or peripheral lymphoid organs (Reichman-Freid et al. 1990; F. Young, R. Phillips, and F. Alt, unpubl.). The inability to consistently rescue the development of peripheral B cells by introduction of immunoglobulin HC and LC transgenes into SCID mice may reflect the pleiotropic nature of the SCID mutation and/ or the ability of a monoclonal B-cell population to efficiently differentiate in the absence of other lymphocytes (Fulop and Phillips 1990; Bosma and Carroll 1991; Riggs et al. 1991).

Mice homozygous for a mutation that inactivates the recombinase activating gene 2 (RAG- $2^{-1}$ mice) cannot initiate $V(D) /$ recombination; both $\mathrm{B}$ - and T-cell development is blocked at the early precursor stages $\left(\mathrm{CD} 43^{+}\right.$ for $\mathrm{B}$ cells and $\mathrm{CD}^{-} / \mathrm{CD} 8^{-}$for $\mathrm{T}$ cells) when $V(D) I$ rearrangement begins (Shinkai et al. 1992). Despite the absence of mature B or T lymphocytes, other cellular components of the immune system (macrophages, NK cells) are unaffected. To study the influence of immunoglobulin HC or LC expression on B-cell differentiation and to further elucidate the requirements for peripheral B-cell development, we have introduced functional immunoglobulin $\mathrm{HC}$ and/or LC transgenes into the RAG$2^{-1-}$ background. Because RAG-2 $2^{-1-}$ cells cannot undergo any endogenous $V(D) /$ rearrangement events, we have been able to assess readily the ability of a given immunoglobulin chain to influence the differentiation of precursor B cells. In addition, these studies have also allowed us to test postulates of current models regarding the role of immunoglobulin $\mathrm{HC}$ and SLC expression in promoting these events. Finally, because the RAG-2 ${ }^{-1-}$ defect is nonleaky and has no known pleiotropic effects, we were able to test unequivocally the requirement for diversified lymphocyte repertoires and $T$ cells in peripheral B-cell development.

\section{Results}

Generation of immunoglobulin transgenic $R A G \cdot 2^{-1-}$ mice

We derived separate lines of immunoglobulin $\mathrm{HC}$ and LC chain transgenic mice to study the effects of expression of the individual HCs and LCs or the complete immunoglobulin molecule on B-cell development in the RAG-2-1- background. The immunoglobulin HC transgene was derived from a genomic clone (Fig. 1B) in which a $V_{\mathrm{H}}$ 186.2, DFL.16, $J_{\mathrm{H}} 2$ rearrangement was fused to a DNA segment that contained the $/_{\mathrm{H}^{-}} \mathrm{C} \mu$ intron, $\mathrm{C} \mu$, and $\mathrm{C} \delta$ genes in germ-line configuration (Goodnow et al. 1988). The C $\delta$ gene was included to preserve the normal expression of immunoglobulin $\delta$ protein in the developing and mature B-cell compartments. The immunoglobulin LC transgene consisted of a $V_{\lambda} 1 J_{\lambda} 1$ rearrangement appended to a $\mathrm{C}_{\lambda} 1$ gene to which the $\mathrm{IgH}$ intronic enhancer element had been added $3^{\prime}$ of the coding sequences (Fig. 1A). Both the $\mathrm{HC}$ and $\mathrm{LC}$ variable $(V)$ region genes were constructed from germ-line (nonsomatically mutated) gene segments. The encoded HCs and LCs, when assembled, form an anti-[4-hydroxy-3-nitrophenylacetyl (NP)] B-cell receptor for which a panel of monoclonal anti-idiotypic reagents are available that detect the $V_{\mathrm{H}}$ alone as well as the $V_{\mathrm{H}} / V_{\mathrm{L}}$ combination (Reth et al. 1979). We generated two lines of mice that harbored either 3 (Fig. 1B, lane 4) or 60 (Fig. 1B, lane 5) copies of the $V_{\mathrm{H}} 186-\mathrm{C} \mu$ transgene (termed $\mathrm{HC} 186 \mathrm{~L}$ and $\mathrm{HC} 186 \mathrm{H}$ mice, respectively) and one line of mice that harbored 5 copies of the $V_{\lambda 1}-C_{\lambda 1} \mathrm{E} \mu$ construct /termed $\lambda \mathrm{E} \mu$ mice; Fig. 1A, lane 2). We then bred the three transgenes into the RAG-2 ${ }^{-1-}$ background $(\mathrm{HC} 186 \mathrm{~L}, \mathrm{HC} 186 \mathrm{H}$, or $\lambda \mathrm{E} \mu$ RAG-2 ${ }^{-1-}$ mice).

Analysis of B-cell development in immunoglobulin $H C$ transgenic $R A G-2^{-1-}$ mice

B-cell differentiation in RAG-2 ${ }^{-1-}$ mice was shown previously to be blocked at the large, $\mathrm{B} 220^{+}, \mathrm{CD} 43(\mathrm{~S} 7)^{+}$ 


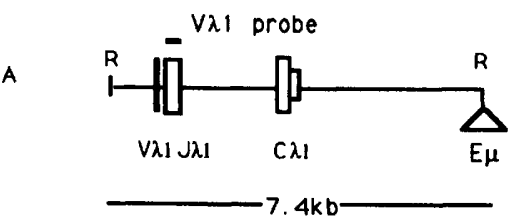

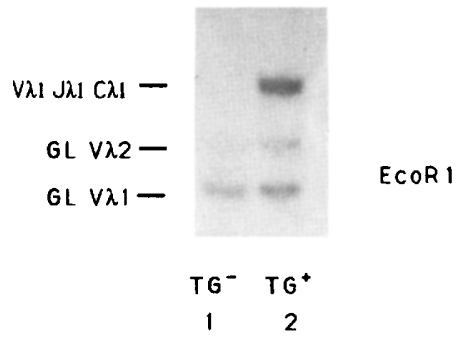

$4 \mathrm{~kb}$

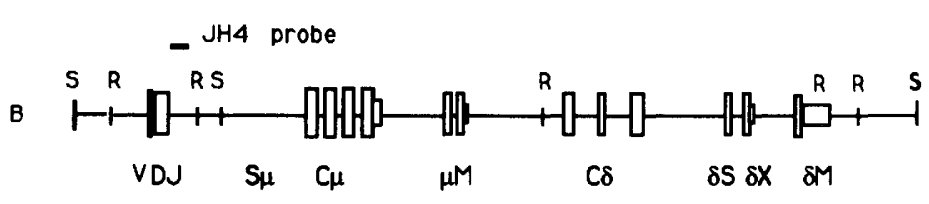

pro-B cell stage, a stage in which the onset of rearrangements of the IgH locus has been shown to occur. This stage is known to precede a small, $\mathrm{B} 220^{+}, \mathrm{CD} 43^{-}$pre-B stage in which $\mathrm{HC}$ rearrangements have been substantially completed and LC gene assembly can be detected at high levels (Ehlich et al. 1993; Li et al. 1993). To assay for effects of the HC transgene (in the absence of any possible LC gene rearrangement or expression) in promoting known changes and to detect potentially new changes in gene expression associated with this step in B-cell differentiation, we examined bone marrow (BM) cell populations from RAG-2 ${ }^{-1-}, \mathrm{HC} 186$ RAG-2 ${ }^{-1-}$ and RAG- $2^{+/-}$controls. We compared relative size and the surface phenotype of BM cell populations using a panel of specific differentiation markers (IgM, CD43, c-kit, and CD2) in the context of the B-lineage CD45R/ B220 surface marker (Figs. 2 and 3). The CD2 analysis was included because CD2, although initially considered a pan $\mathrm{T}$-cell marker has been found previously on murine splenic B cells and in $\mu^{+}$pre-B-cell lines (Yagita et al. 1989; Sen et al. 1990).

Normal BM contains $\mathrm{B} 220^{\mathrm{lo}}$, $\mathrm{IgM}^{-}, \mathrm{IgD}^{-}$, pro/pre-B cells, $\mathrm{B}_{220^{\mathrm{lo}}}, \mathrm{IgM}^{+}, \mathrm{IgD}^{-}$newly generated $\mathrm{B}$ cells, and $\mathrm{B}_{2} 20^{\text {bright }}$, $\mathrm{IgM}^{+}, \mathrm{IgD}^{+}$, mature $\mathrm{B}$ cells. In the $\mathrm{BM}$ of RAG- $2^{-1}$ mice, most B220 $0^{+}$cells are large (Fig. 3, top) and are at the $\mathrm{IgM}^{-}, \mathrm{CD}^{+} 3^{+}, \mathrm{B}_{2} 20^{+}$and $\mathrm{CD} 2^{-}$stage; a substantial proportion of these cells are c-kit ${ }^{+}$(Fig. 2, cf. columns 1 and 2). In contrast, both $\mathrm{HCl} 86 \mathrm{~L}$ and HC186H RAG-2 ${ }^{-1}$ mice develop a significant popula- tion of small B220 ${ }^{+}$cells (Fig. 3, top; data not shown); the cells in these $\mathrm{BM}$ cells are $\mathrm{IgM}^{-}, \mathrm{B} 220^{\mathrm{lo}}, \mathrm{CD}^{-} 3^{-}$, c-kit ${ }^{-}, \mathrm{CD}_{2}{ }^{+}$cells similar to a population observed in RAG- $2^{+/-}$control mice (Fig. 2, column 4).

The percentage of lymphocytes in the $\mathrm{IgM}^{-}, \mathrm{CD}^{-} 3^{-}$, $\mathrm{B} 220^{+}, \mathrm{c}-k i t^{-}, \mathrm{CD} 2^{+}$population was variable, ranging from 0.8 to 2.2 times that in age-matched normal mice (Fig. 2; data not shown). The development of a small $\mathrm{B} 220^{+}$population of cells that have lost $\mathrm{CD} 43$ and c-kit expression in HC186 RAG-2 ${ }^{-1-}$ bone marrows indicated that the expression of the HC transgene, in the absence of any endogenous variable region gene rearrangements, effected this developmental transition with respect to surface marker expression. Likewise, these studies demonstrate that surface expression of CD2 is a new positive marker associated with this developmental transition.

Expression of $\mu$ chains by HC186, RAG-2-1- BM cells

Cytoplasmic staining with fluorescent anti- $\mu$ antibodies demonstrated that most of the HC186 RAG-2 ${ }^{-1-}$ BM cells that expressed $\mathrm{B} 220^{+}$also expressed $\mu$ chains /data not shown). However, upon multiple attempts, we could detect no cells in these populations from either $\mathrm{HCl}$ 86L or $\mathrm{HCl} 86 \mathrm{H}$ RAG-2 $2^{-1-}$ BM that showed surface staining above the background level with anti- $\mu$ reagents (HC186L RAG-2 $2^{-1-}$ BM staining is shown in Fig. 3B). 
Figure 2. Flow cytometry analysis of $B M$ cell-surface markers in $\mathrm{HCl} 86$ and $\lambda \mathrm{E}_{\mu}$ complemented RAG- $2^{-1-}$ mice. Results are presented as two-dimensional dot plots in which each dot represents an individual cell. The genotype of the animal from which the BM cells were obtained appears above each vertical panel (e.g., RAG-2 ${ }^{+/-}$). Plots were generated from dots falling within the lymphocyte gate, as defined by size and light scatter analysis. Horizontal $A$ compares the staining pattern of BM cells stained with fl-anti-B220 and bi-anti-IgM from HC- or LC-complemented animals and nontransgenic littermate controls. $(B)$ BM cells stained with PE-anti-B220 and flanti-CD43 (S7). (C) BM cells stained with fl-anti-B220 and bi-anti-c-kit. (D) BM cells stained with fl-anti-B220 and bi-anti-CD2. Biotinylated reagents anti-\{IgM, c-kit, CD2) were revealed with streptavidin-PE (Pharmingen). The staining patterns in each horizontal panel are from one experiment and are representative of at least three independent experiments.
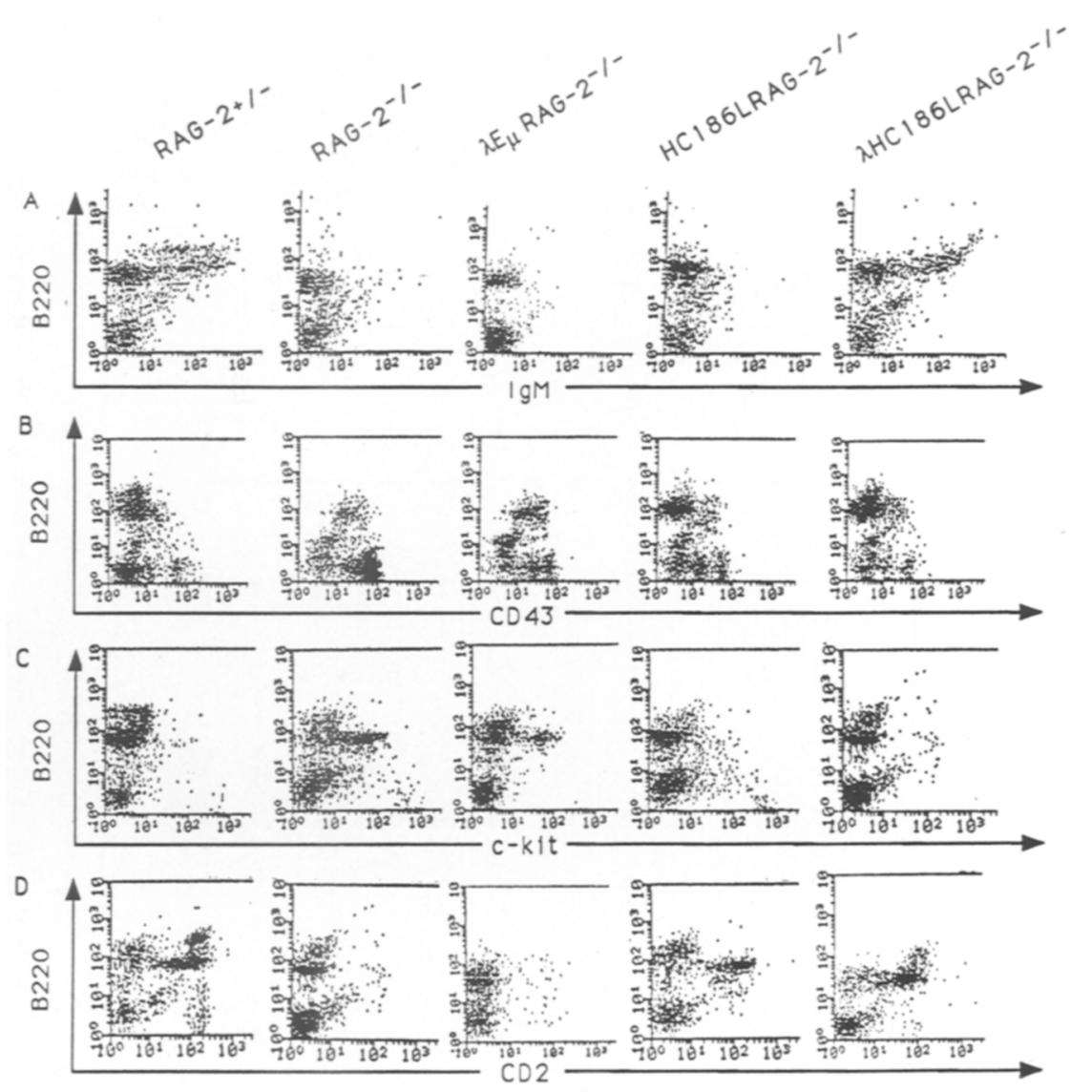

Finally, as a control, $\mu$-positive cells were readily detected in RAG-2 $2^{+1-}$ BM cells (Figs. 2B and 3B).

To assay further for expression of $\mu$ chains and associated proteins, we metabolically labeled the $\mathrm{HCl}$ (86L RAG-2 ${ }^{-1-}$ BM populations with $\left[{ }^{35} S\right]$ methionine/cysteine, precipitated the labeled lysates with an anti- $\mu$ antiserum, and analyzed the complexes by two-dimensional nonreducing/reducing polyacrylamide gel electrophoresis (SDS-PAGE). In this analysis, the $\mu$ protein was detected as free HCs, monomers and dimers (Fig. 4A). Intracellular $\mu$ was covalently associated with a $46-\mathrm{kD}$ protein, and a $22-\mathrm{kD}$ protein (Fig. $4 \mathrm{~A}$ ). The identity of the larger associated species is not known; however, the smaller species corresponds in size to $\lambda_{5}$ (Pillai and Baltimore 1987; Karasuyama et al. 1990, 1993; Tsubata and Reth 1990; Misener et al. 1991; Nishimoto et al. 1991; Lassoued et al. 1993). A parallel analysis of metabolically labeled BCL1 (murine lymphoma) cells showed only 26to $28 \mathrm{kD}$ proteins that correspond in size to conventional $\lambda$ LC covalently associated with $\mu$ chains (not shown|. To assay more sensitively for expression of surface $\mu$ chains on HC186L RAG-2 ${ }^{-1-}$ or RAG-2 ${ }^{+/-}$pre-B cells, we labeled surface proteins on intact mononuclear cells with ${ }^{125} \mathrm{I}$ and analyzed labeled proteins by SDSPAGE following precipitation with anti- $\mu$. Although we detected precipitated protein species of molecular weights consistent with $\mu$ chains and conventional LCs in control BM cells, no $\mu$ chains or proteins of the size of
SLC were detected from the HC186 RAG-2 ${ }^{-1-}$ BM lysates (data not shown).

\section{Analysis of cultured BM B-lineage cells from HC186 RAG-2 ${ }^{-1-}$ mice}

To compare further the characteristics of B-lineage cells in HC186L RAG-2 $2^{-1-}$ with B-cell populations in control mice, we attempted to generate lymphoid cultures from their BM cells. Whereas we could routinely establish proliferating cultures from RAG-2 ${ }^{-1-}(7 / 9$ attempts) or RAG-2 ${ }^{+1-}(8 / 9$ attempts) BM, none could be established from the BM of $\mathrm{HCl} 86 \mathrm{~L}$ RAG- $2^{-1-}$ or HC186L RAG-2 $+1-(0 / 9$ attempts) mice under longterm lymphoid culture conditions that did not include recombinant interleukin-7 (IL-7; Whitlock and Witte 1982). However, we could establish cultures from the BM of all mice when primary cells were plated at high density (see Materials and methods) in media supplemented with IL-7. Under these conditions, RAG-2 ${ }^{+1}$ or -1- BM generated a significant population of nonadherent, $\mathrm{B}_{2} 20^{+}$cells between days 3 and 5 of culture; these cells doubled approximately every $20 \mathrm{hr}$ and could be maintained up to 4 weeks. In contrast, the HCl86L RAG-2-1- BM cultures did not generate significant B220+ populations until 6-9 days after plating (data not shown). These cells doubled approximately every $36 \mathrm{hr}$ and could not be maintained for $>2$ weeks after $\mathrm{B} 220^{+}$ 


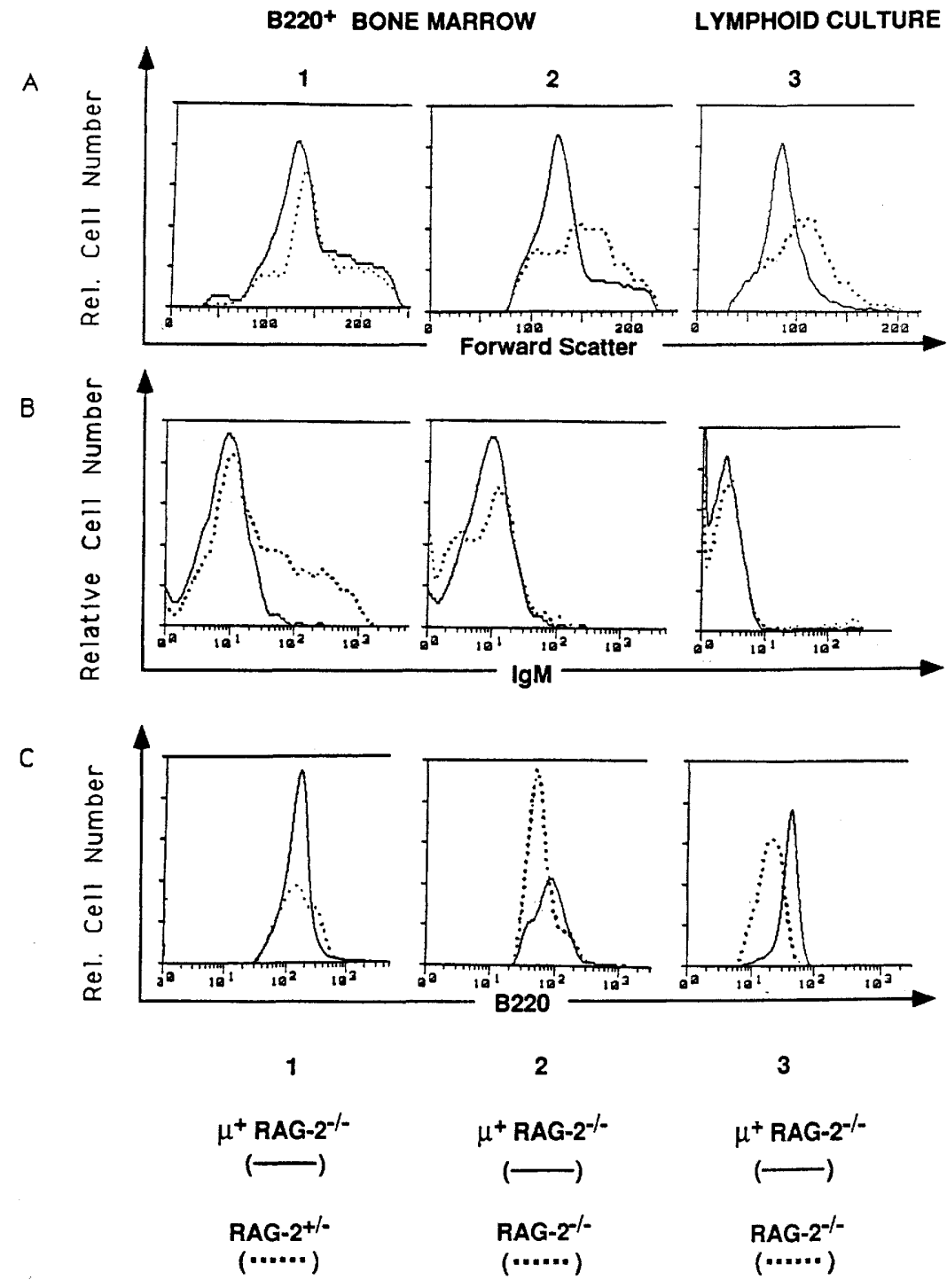

Figure 3. Comparison of $\mathrm{B} 220^{+} \mathrm{BM}$ cells and IL-7-lymphoid cultures from HC186 RAG-2 -1mice and controls. (Columns 1,2) The relative cell number (vertical axis) of the $\mathrm{B} 220^{+}$gated cells in each BM is shown as a histogram depicting forward scatter (an indication of cell size) of the gated population $(A)$, relative fluorescence with PE-labeled anti-IgM, $(B)$ and relative fluorescence with $P E-$ labeled anti-B220 $|C|$. In all experiments, HC186L RAG-2-1- BM-derived cells are represented by the solid line. (Column 3) Comparison of the characteristics of cells that grew in IL-7-supplemented in vitro BM cultures from mice represented in the first two columns. In these cultures, $>90 \%$ of the nonadherent cells were $\mathrm{B} 220^{+}$. Lymphoid cells from RAG-2+1cells that grew under these conditions were indistinquishable from those of the RAG- $2^{-1-}$ cultures when analyzed by forward scatter or for surface expression of $\operatorname{IgM}$ and B220. (data not shown) cell expansion became apparent (data not shown). Compared with cells in the RAG-2 ${ }^{-1-}$ and RAG-2 $2^{+/-}$cultures, cells in the $\mathrm{HC} 186 \mathrm{~L}$ RAG- $2^{-1-}$ cultures were smaller and more brightly staining for surface B220 (Fig. $3 \mathrm{~A}, \mathrm{C}$, column 3$)$. We readily detected surface $\mu^{+}$cells $(5-40 \%)$ in IL-7-supplemented HC186L RAG-2 ${ }^{+/-}$cultures, which presumably reflects the development of $\mathrm{IgM}^{+}$cells (data not shown). However, we could not detect surface expression of $\mu$ chains on the cells in any of the HC186L RAG-2 $2^{-1-}$ cultures by immunoflourescent staining (Fig. 3B, column C).

To characterize the growth characteristics of $B$-lineage cells in HC186L RAG-2 ${ }^{-1-}$ mice, we assayed for incorporation of $\left[{ }^{3} \mathrm{H}\right]$ thymidine after 5 days of incubation in IL-7 (Fig. 5A). We observed significant incorporation in the wells plated with BM from $\mathrm{RAG}-2^{-1-}$ and RAG$2^{+1-}$ littermates in the presence of IL-7 but not a control lymphokine (interleukin-4). However, we found no incorporation above background in the IL-7-supplemented
BM cultures from either the HC186L RAG- $2^{-1-}$ or the HC186L RAG-2 ${ }^{+1-}$ mice (Fig. 5A). To investigate further this apparent difference in IL-7 responsiveness, equal numbers of $\mathrm{B} 220^{+}$cells from established lymphoid cultures were plated onto genotypically matched mitomycin-treated BM stroma, and aliquots of nonadherent cells were counted on consecutive days (Fig. 5B). Although there was no significant difference in the number of nonviable cells in each culture, under these conditions cells from the RAG-2 $2^{-1-}$ and RAG-2 $2^{+1-}$ cultures doubled $\sim 1.6$ times the rate of those from the HC186L RAG$2^{+1-}$ or HC186L RAG-2 $2^{-1-}$ cultures (Fig. 5B). Finally, by limiting-dilution analysis, the frequencies of IL-7 and stromal cell reactive pro/pre-B cells in the $\mathrm{BM}$ of $\mathrm{HCl} 186 \mathrm{~L}$ and $\mathrm{HCl} 186 \mathrm{H}$ RAG-2 $2^{-1-}$ mice were enumerated. Compared with age-matched BM from RAG-2 $2^{-1-}$ or $\mathrm{RAG}-2^{+/}$mice, these numbers were reduced 10- to 20fold in both $\mathrm{HCl} 186 \mathrm{RAG}-2^{+/-}$or RAG-2 ${ }^{-1-}$ mice /data not shown). Together, these results suggest that expres- 

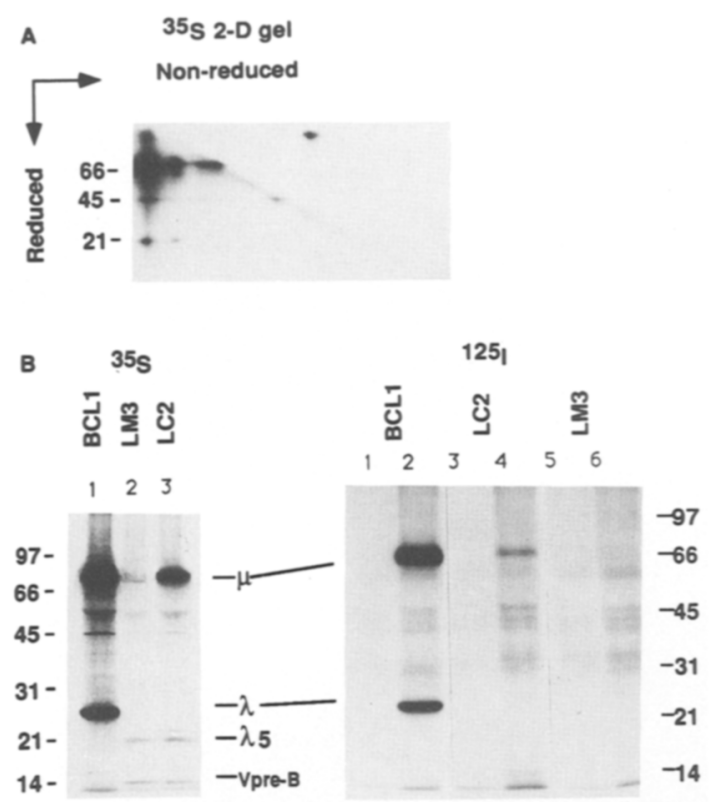

Figure 4. Biochemical analysis of $\mathrm{HC}$ associated proteins in HC186 RAG-2 ${ }^{-1-}$ mice and A-MuLV transformants. (A) Primary BM cells from HC186L RAG-2 ${ }^{-1-}$ mice were metabolically labeled with $\left[{ }^{35} \mathrm{~S}\right]$-methionine and the $\mathrm{HC}$-associated proteins separated by two-dimensional PAGE electrophoresis following anti- $\mu$ immunoprecipitation. Three species of $\mathrm{HC}$ protein $(70 \mathrm{kD})$ are resolved: monomers (on the diagonal), homodimers, and a heterodimer consisting of two proteins $146 \mathrm{kD}$ and $22 \mathrm{kD}$ ) distinct from the $\mathrm{HC}$. In a separate, one-dimensional analysis, the $22-\mathrm{kD}$ protein was seen to comigrate with a $22-\mathrm{kD}$ protein immunoprecipitated with anti- $\lambda$ antibodies from RAG$2^{-1-}$ BM (data not shown). (B) (Left) One-dimensional PAGE analysis of precipitates from metabolically labeled cell extracts: The AMuLV-transformed RAG-2-1- line LM3 (lane 2) and HC186 RAG-2 $2^{-1}$ derived line LC2 (lane 3), as well as the control lymphoma cell line BCLl $\left(\mu \lambda^{+}\right.$, lane 1$)$, were analyzed. Extracts shown in lanes 1 and 3 were immunoprecipated with anti- $\mu$; lane 2 was immunoprecipated with anti- $\lambda$. (Right) All three cell lines were surface labeled with ${ }^{125} I$, and immunoprecipitated with either normal goat senum (lanes $1,3,5$ ) or anti- $\mu$ (lanes $2,4,6$ ). The migration pattern of protein molecular mass markers is indicated for each gel; putative protein species are indicated between $A$ and $B$.

sion of $\mu$ protein generates a population of differentiating $B$ cells in which the proliferative response to IL-7 is substantially decreased.

\section{Analysis of $A-M u L V$ transformed pre-B cells from $H C$ $R A G-2^{-1-}$ mice}

To assay for $\mu$-chain expression on pre-B lines established from $\mathrm{HCl} 186 \mathrm{RAG}-2^{-1-}$ mice, we established eight Abelson murine leukemia virus (A-MuLV)-transformed lines from these mice. All of the A-MuLV-transformed HC186 RAG-2 ${ }^{-1-}$ pre-B-cell lines expressed the standard sets of transcripts characterized previously for such lines (Schlissel et al. 1991), as well as mature $V(D) I-C \mu$ transcripts from the $\mathrm{HC} 186$ transgene (data not shown). To determine whether the transgenic $\mu$ chain associated intracellularly with SLCs, we metabolically labeled these cells with ${ }^{35} \mathrm{~S} \mid$ methionine/cysteine and assayed for $\mu$-associated proteins by SDS-PAGE analysis following anti- $\mu$ precipitation (Fig. 4). Analyses of HC186L RAG-2 ${ }^{-1-}$ pre-B-cell lysates revealed $\mu$-associated proteins of the sizes predicted for $\lambda_{5}$, and $\mathrm{V}_{\text {preB }}$ (Fig. $4 \mathrm{~B}$, left, lane 3). Lysates from control BCL1 lymphoma

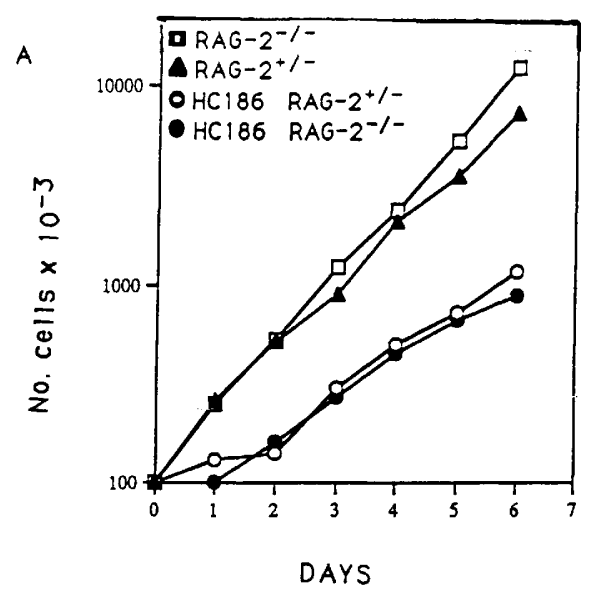

8

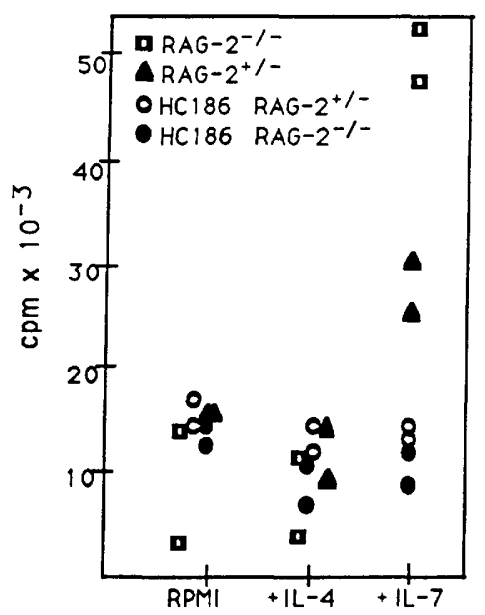

Figure 5. IL-7 stimulation of in vitro cultures and of bone marrow cells is affected by presence of an $\mathrm{HC}$ transgene. $(A)$ Uptake of $\left[{ }^{3} \mathrm{H}\right]$-thymidine by BM cells plated in RPMI, or RPMI containing IL-4, or IL-7 $(200 \mathrm{U} / \mathrm{ml})$. Cells $\left(5 \times 10^{4}\right.$ were plated in triplicate wells, and pulsed with $\left[{ }^{3} \mathrm{H}\right]$ thymidine after $60 \mathrm{hr}$. Each symbol represents the average of radioactive counts in triplicate wells from RAG-2-1- -derived cultures $(\square), \mathrm{RAG}-2^{+1-}$-derived cultures $(\mathbf{\Delta}), \mathrm{HC1}$ 86L complemented RAG-2 $2^{-1-}(0)$ or $\mathrm{HC1} 186 \mathrm{~L}$ RAG- $2^{+1-}$ cultures $(O)$; two independent experiments are shown. (B) Growth curve of IL-7-supplemented BM cultures from HC186L-complemented mice and control animals. The curve reflects the cell numbers in IL-7 supplemented BM cultures. On day $0,10^{5}$ cells from established ( 10 day old) cultures were plated onto genotypically matched stromal layers, and counted at six 24-hr intervals. Each point is the mean of three separate cultures that were simultaneously derived (from two animals each) and maintained in parallel. Stroma were treated with mitomycin-C so that only dividing lymphoid cells are reflected in the cell numbers. 
cells $\left(\mu \lambda^{+}\right)$contained only conventional $\lambda$ LCs associated with $\mu$ (Fig. 4B); no $\mu$ chains or chains the size of SLC were detected in precipitations from control RAG-2 ${ }^{-/-}$ pre-B lines (data not shown). In accord with the interpretation that the associated chains seen in the HCl86 RAG-2 ${ }^{-1-}$ pre-B-cell lysates were SLCs, a $\lambda_{5}$-sized chain was precipitated from a $\mathrm{RAG}-2^{-1-} \mathrm{A}-\mathrm{MuLV}$ transformant (Fig. 4B, left, lane 2) and a HC186 RAG-2-1A-MuLV transformant (not shown) with an anti- $\lambda$ antibody that also recognizes the $\lambda_{5}$ chain (Tsubata et al. 1992).

A membrane complex composed of immunoglobulin $\mu$ protein plus the $\lambda_{5}$ and $V_{\text {pre-B }}$ SLCs has been detected on the surface of $\mu^{+}, \mathrm{k}^{-}$A-MuLV-transformed pre-B cell lines (Pillai and Baltimore 1987; Kerr et al. 1989; Takemori et al. 1990; Misener et al. 1991) and on the surface of B-cell lines transfected with appropriate expression vectors (Tsubata and Reth 1990). Despite the fact that the HC186L RAG-2-1- and HC186H RAG-2-1- AMuLV lines expressed readily detectable cytoplasmic $\mu$ chains, we could not detect surface $\mu$ chain on any of these by immunofluorescence analyses (data not shown). To assay more sensitively for expression of surface $\mu$ chains on HC186L RAG-2 ${ }^{-1-}$ or RAG- $2^{+/-}$pre-B cells, we labeled surface proteins with ${ }^{125} \mathrm{I}$ as described above and analyzed labeled proteins by SDS-PAGE following precipitation with anti- $\mu$ antibodies (Fig. 4B). Under these conditions, we readily detected the surface $\mu \lambda$ chains on BCL1 B-lymphoma cells. Unexpectedly, compared with RAG-2 ${ }^{-1-}$ controls, low levels of surface $\mu$-chain expression could be detected on the surface of HC186L RAG-2 ${ }^{-1-}$ A-MuLV transformants (Fig. 4B, right) despite our inability to detect such chains by surface immunofluorescence analyses. However, we could not detect any associated chains in the precipitates that comigrated with SLCs (Fig. 4B). As a control for surface labeling, we did not detect tubulin chains /which are cytoplasmic) following anti-tubulin antibody precipitation of these cell extracts (data not shown).

Together, these data are generally in accord with those from analyses of $\mathrm{HCl} 186 \mathrm{RAG}-2^{-1-} \mathrm{BM}$ cells and confirm that the transgenic $\mu$ protein associates with components of the pre-B-cell receptor, which can be detected intracellularly, but not readily detected on the cell surface, at this stage of differentiation.

Expression of immunoglobulin LC does not effect differentiation of the RAG-2-1- Pro-B population

Recently, studies of HC-deficient or $\lambda_{5}$-deficient mice led to the suggestion of a minor pathway of B-cell development in which LC gene rearrangement precedes that of $\mathrm{HC}$, generating B cells that bypass the small pre-B-cell stage (Chen et al. 1993; Ehlich et al. 1993). To determine whether transgenic immunoglobulin LC expression in the absence of immunoglobulin $\mathrm{HC}$ rearrangement or expression has any detectable affect on pro-B-cell differentiation, we assayed surface antigen profiles as well as growth characteristics of BM cultures of $\lambda \mathrm{E} \mu \mathrm{RAG-2^{-1- }}$ mice. Comparison of surface staining profiles for B220,
$\mathrm{CD} 43$, c-kit, and $\mathrm{CD} 2$ on the BM populations of $\lambda \mathrm{E} \mu$ RAG-2 ${ }^{-1-}$ mice with those of nontransgenic RAG$2^{-1-}$ littermates revealed no significant differences (Fig. 2). Therefore, $\lambda$ LC expression, in the absence of immunoglobulin $\mathrm{HC}$ expression, had no discernible effect on pro-B-cell differentiation.

Effects of HC transgene expression on $\lambda_{5}$ and germline $\mathrm{\kappa}$ transcript expression in $R A G-2^{-1-} B M$ cells

To study the effect of $\mathrm{HC}$ protein expression on gene expression in RAG-2 $2^{-1-}$ BM cells, we also assayed RNA prepared from BM cells of HC186L RAG-2 $2^{-1-}$ mice as well as that from RAG-2 $-1-$ and RAG-2+1- littermate controls to assay for expression of $\lambda_{5}$ and germ-line $k$ transcripts (which initiate upstream of the unrearranged $J_{\kappa}$ locus; Van Ness et al. 1981). The effect of HC expression on the generation of the latter transcripts in RAG$2^{-1-}$ B-cell precursors was of particular interest, because their expression has been correlated with accessibility of the $\kappa$ locus for $V(D) /$ recombination (Schlissel and Baltimore 1989).

Prior to RNA extraction, the percentage of $\mathrm{B} 220^{+}$cells in each sample was determined. BM samples containing comparable numbers of $\mathrm{B} 220^{+}$cells $\left(15-20 \% \mathrm{~B} 220^{+}\right)$ were used in the analysis. To control for the relative number of B-lineage cells in each preparation, we hybridized the blots sequentially with $\kappa, \lambda_{5}$, and MB-1-specific probes; the MB-1 expression level was used as a control because this gene has been found to be expressed at similar levels in all classes of differentiating B-lineage cells in the BM (Sakaguchi et al. 1988; Li et al. 1993). Comparison of relative signal intensities indicated that the level of $\lambda_{5}$ expression (as compared with MB-1 expression) was reproducibly lower by approximately fivefold in RNA from HC186L RAG-2 ${ }^{-1}$ BM samples (three independent mice) as compared with that in RNA from RAG-2 ${ }^{-1-}$ BM cells (four independent mice) (Fig. 6; representative data are shown). These data, together with

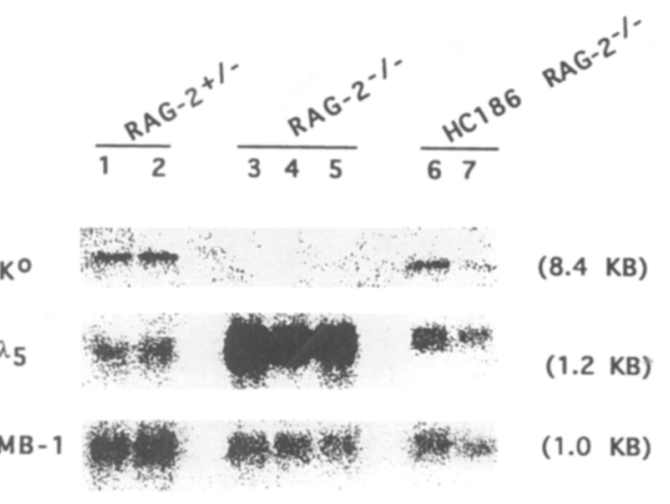

Figure 6. Expression of B-lineage genes in HC186L RAG-2 ${ }^{-1-}$ $\mathrm{BM}$. Approximately $12 \mu \mathrm{g}$ of total RNA from the indicated BM sources was assayed for hybridization to $\kappa\left(\kappa^{\circ}\right), M B-1$, and $\lambda_{5}$ probes. The size of the hybridizing mRNA transcript $(\mathrm{kb})$ is indicated (right). Data shown are representative of individual mice, from two independent experiments. 
the fact that the RNA was prepared from comparable numbers of $\mathrm{B} 220^{+}$cells, indicate that expression of $\lambda_{5}$ transcripts are down-regulated subsequent to the expression of HC protein. When the same blots were assayed for expression of germ-line $k$ transcripts (with a genomic probe derived from sequences upstream of $\kappa$ locus-coding regions, termed $\kappa^{\circ}$ probe; Van Ness et al. 1981), we detected no signals in RNA from RAG-2 ${ }^{-1-}$ BM (Fig. 6, lanes 3-5). As expected, the 8.4-kb germ-line $\kappa$ transcripts were detectable in RNA from RAG-2 ${ }^{+1-}$ controls (Fig. 6, lanes 1,2). Significantly, this same hybridization also revealed readily detectable 8.4-kb germ-line transcripts in all BM-derived RNA samples of $\mathrm{HCl}$ 86L RAG-2 ${ }^{-1}$ mice (Fig. 6, lanes 6,7). Together, these findings indicate that expression of the $\mathrm{HC}$ transgene in RAG- $2^{-1-}$ pro-B cells generates a new population of cells with decreased steady-state levels of $\lambda_{5}$ transcripts and greatly increased levels of germ-line $\kappa$ transcripts.

Reconstitution of a functional peripheral B-cell population in immunoglobulin $\mathrm{HC} / \mathrm{LC}$ RAG-2 ${ }^{-1-}$ mice

We bred HC186L and $\lambda \mathrm{LC}$ transgenic RAG-2 $2^{-1-}$ mice to generate double transgenic $\left(\lambda \mathrm{HC} 186 \mathrm{RAG}-2^{-1}-1\right.$ mice. The number and composition of the $\mathrm{BM} \mathrm{B} 220^{+}$cell populations of the HC/LC RAG-2-1- mice were, essentially, indistinguishable from those of $\mathrm{HC} / \mathrm{LC}$ control transgenics with respect to expression of the various surface markers analyzed (Fig. 2). Likewise, BM cultures established from $\lambda \mathrm{HCl} 86 \mathrm{RAG}-2^{+/-}$or $\lambda \mathrm{HCl} 86 \mathrm{RAG}-$ $2^{-1-}$ littermates were essentially identical in phenotype with $>90 \%$ of the cells expressing surface IgM; the IgM ${ }^{+}$ cells in these cultures were smaller in size and expressed higher levels of B220 than cultures from nontransgenic controls (data not shown).

The spleens of $\lambda \mathrm{HCl} 186 \mathrm{RAG}-2^{-1-}$ mice /ranging in age from 3 to 10 weeks) were variable in size. All of the spleens examined contained substantial numbers of $\lambda^{+}$, $\operatorname{IgM}^{+}, \operatorname{IgD}^{+}$cells; based on additional characteristics [e.g. cell size, complexity, and surface levels of heat stable antigen (HSA), Allman et al. 1992], the general phenotype of these cells corresponded to that of immature $B$ lymphocytes. The number of $\mathrm{B}^{2} 20^{+}$cells in $\lambda \mathrm{HCl} 86$ RAG- $2^{-1-}$ spleens was $\sim 30-50 \%$ of the number of $\mathrm{B}_{2} 20^{+}$cells found in age-matched $\lambda \mathrm{HCl} 86 \mathrm{RAG}-2^{+1-}$ mice (Fig. 7A; data not shown). However, as expected, no mature $\mathrm{T}$ celis were detected in the spleens or thymuses of $\mathrm{HCl} 186, \lambda \mathrm{E} \mu$, or $\lambda \mathrm{HCl} 86 \mathrm{RAG}^{-1}{ }^{-1}$ mice (data not shown). In the spleens of $\lambda \mathrm{HC} 186 \mathrm{RAG}-2^{-1-}$ mice, all of the $\mathrm{B}_{2} 20^{+}$cells were $\lambda^{+}$and bound the Ac38 monoclonal antibody (Fig. $7 \mathrm{~B}$; data not shown); the latter reagent is an anti-idiotypic antibody specific for the $V_{\mathrm{H}} 186.2 / \lambda_{1}$ chain combination. Thus, the $\lambda \mathrm{HC} 186$ transgenic mice contained a population of $B$ cells that were monoclonal with respect to surface receptor expression. To test whether the peripheral B cells in $\lambda$ HC186 RAG-2 $2^{-1-}$ mice were functional, we measured serum immunoglobulin levels in these mice. Serum IgM levels in 4-weekold $\lambda \mathrm{HCl} 86 \mathrm{RAG}-2^{-1-}$ animals were within the range found in normal and transgenic control mice (Fig. 8). Likewise, the B-lineage cells from the mice responded to in vitro lipopolysaccharide treatment by proliferating and secreting IgM (data not shown).

\section{Discussion}

Immunoglobulin complementation of RAG-2 ${ }^{-/-}$ mice promotes $B$-cell differentiation

B-cell differentiation is blocked at the pro-B-cell stage in RAG-2-deficient mice, a stage in which HC $D$ to $/$ rearrangement normally has begun. We have shown that introduction of immunoglobulin $\mathrm{HC}$, but not LC, trans-
Figure 7. B cells in the spleen of $\lambda \mathrm{HC} 186 \mathrm{RAG}$ $2^{-1-}$ mice. Surface expression of immunoglobulin on splenocytes of a 3-week-old $\lambda$ HC186 RAG$2^{-1-}$ mouse and littermate controls was detected with fl-anti-IgD and PE-anti-IgM ${ }^{a}|A|$, and fl-anti- $\kappa$ and PE-anti- $\lambda l(B)$.

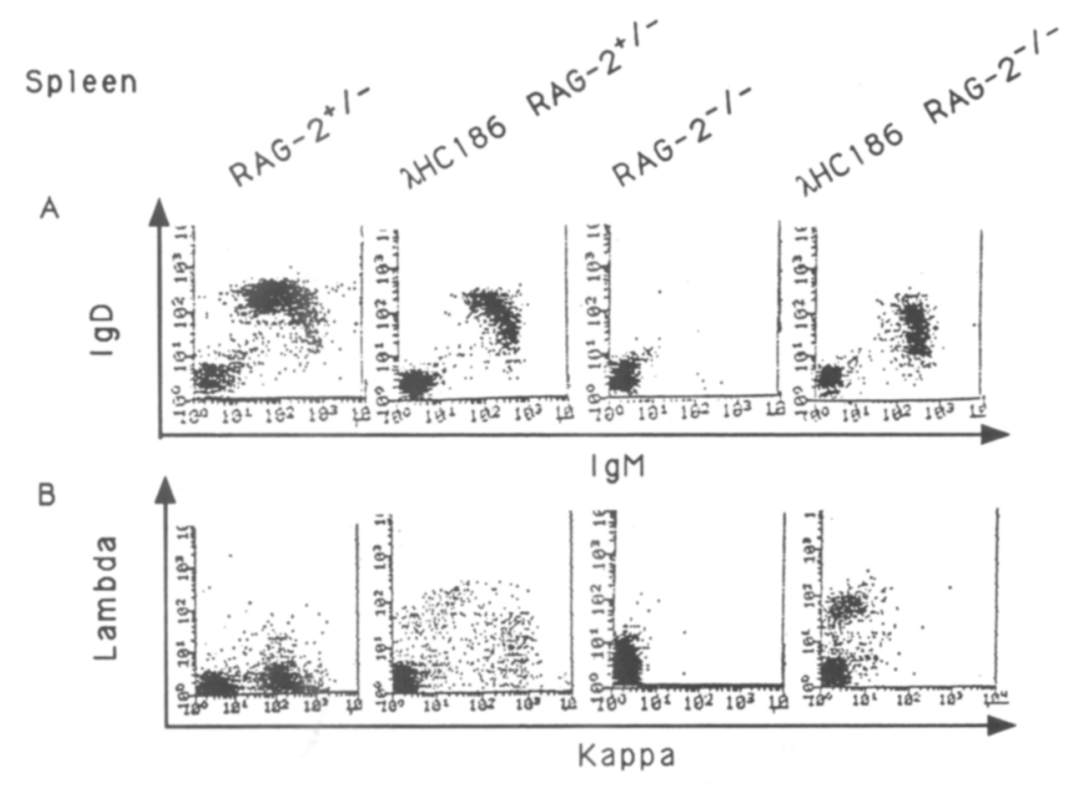




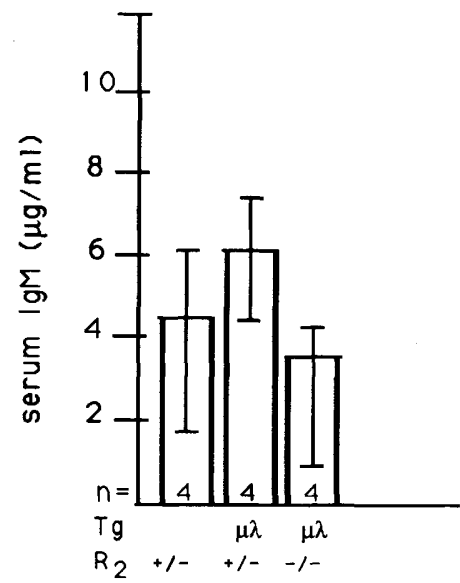

Figure 8. Secretion of IgM by peripheral B cells in $\lambda \mathrm{HC} 186$ RAG-2 $^{-1-}$ mice. Sera from four 5-week-old $\lambda$ HC186 RAG$2^{-1-}$ mice and littermate controls were tested by ELISA for IgM (shown in $\mu \mathrm{g} / \mathrm{ml}$ ). Approximately $30 \%$ of the serum IgM in $\lambda \mathrm{H} 186 \mathrm{RAG}-2^{+1-}$ animals is idiotype positive, whereas $100 \%$ of the IgM in $\lambda \mathrm{HC} 186 \mathrm{RAG}-2^{-/-}$animals is idiotype positive (data not shown).

genes into the RAG-2-/- background promotes the appearance of a BM cell population that has many of the phenotypic attributes of the pre-B-cell stage. We have shown further that simultaneous introduction of immunoglobulin $\mathrm{HC}$ and $\mathrm{LC}$ transgenes into the $\mathrm{RAG}-2^{-1-}$ background leads reproducibly to the generation of a large population of functional, peripheral $\operatorname{sIgM}^{+} \mathrm{B}$ lymphocytes. The generation of these peripheral B-cell populations is not transgene-dependent, as we have observed similar results with a separate set of HC and LC transgenes (F. Young, C. Goodnow, and F. Alt, unpubl.). All of these differentiation events occur in the complete absence of mature T-lineage cells.

\section{Expression of germ-line $\kappa L C$ transcripts is enhanced in HC186 RAG-2 $2^{-1-} B M$}

The majority of normal differentiating B-lineage cells rearrange HC genes before those of LCs (Coffman and Weissman 1983). High levels of HC germ-line transcripts are the first immunoglobulin transcripts detectable in fetal ontogeny; $\mathrm{k}$ germ-line transcripts generally are detected after the appearance of $\mathrm{HC}$ transcripts (Siden et al. 1981; Lennon and Perry 1990|. Analyses of transformed cell lines have correlated $\mu \mathrm{HC}$ expression with rearrangement of LC loci (Reth et al. 1985; Iglesias et al. 1991). The expression of $\mu \mathrm{HCs}$ appears to promote the differentiation of pro-B-cells in the BM to a small pre-Bcell stage where $\mathrm{K}$ LC gene rearrangements are accumulated (Lee et al. 1989; Hardy et al. 1991, Kitamura et al. 1991; Chen et al. 1993; Ehlich et al. 1993; Li et al. 1993). Our current demonstration that HC186L RAG-2 ${ }^{-1-}$ BM contains levels of germ-line $\mathrm{K}$ transcripts comparable with normal BM samples provides direct evidence that B-lineage cells, in-vivo, up-regulate transcription of the unrearranged $\kappa$ locus subsequent to $\mu$ production. As several studies have strongly correlated either transcription or closely associated processes with targeting genes for $V(D) /$ recombination (Blackwell et al. 1986; Schlissel and Baltimore 1989|, these data provide evidence that $\mu$-chain expression may effect molecular mechanisms that promote the onset of $\kappa$ LC gene rearrangement in vivo.

\section{Differential role for immunoglobulin $H C$ and $L C$ in promoting early $B$-cell differentiation}

We could discern no discrete effect of transgenic $\lambda \mathrm{LC}$ expression on B-cell differentiation in RAG-2 ${ }^{-1}$ mice. However, expression of the $\mathrm{HC} 186$ transgene efficiently signaled the development of small B $220^{\mathrm{lo}} \mathrm{B}$-cell precursors that lose both CD43 and c-kit while gaining CD2 expression. The number and phenotype of these cells is indistinguishable from the corresponding population in normal BM cells. Similar findings have been made in studies of immunoglobulin HC-complemented SCID and $J_{\mathrm{H}}{ }^{-1-}$ mice /Chen et al. 1993; Reichman-Freid et al. 1993); however, these analyses could not rule out potential influences of endogenous immunoglobulin gene rearrangement.

Changes in surface antigen expression accompany functional maturation during the differentiation of precursor B cells. Studies of HC186 RAG-2 $2^{-1-}$ BM and BM cultures from these mice demonstrate the up-regulation of surface CD45R/B220 and the appearance of CD2 on the surface of $\mu^{+}$pre-B cells. CD45 is a protein tyrosine phosphatase that is required for IgM-mediated proliferation (Justement et al. 1991; Kishihara et al. 1993) and, in $\mathrm{T}$ cells, is physically and functionally interrelated with the signaling molecule, CD2 (Pingel et al. 1989; Schraven et al. 1990; Koretzky et al. 1991). CD2, which we now show to be a very specific marker for the $\mu^{+}$ developmental stage, is involved in cell-cell interactions (Springer et al. 1987; Albert-Wolf et al. 1991) and is expressed throughout later stages of B-cell development (Yagita et al. 1989; Sen et al. 1990).

In $\mathrm{RAG}^{-1-}$ mice, $\mathrm{T}$-cell precursors are large, $\mathrm{CD}_{2}^{-}$, c-kit ${ }^{+}$, IL-7-responsive cells whose counterparts in normal thymus are found in the $\mathrm{CD}^{-}, \mathrm{CD} 8^{-}$double-negative (DN) population (Murray et al. 1989; Mombaerts et al. 1992; Shinkai et al. 1992). Complementation with a functionally assembled T-cell receptor $\beta$ (TCR $\beta$; but not $\mathrm{TCR} \alpha$ ) transgene promotes thymocyte differentiation to the small, $\mathrm{CD} 2^{+}, \mathrm{c}-k i t^{-}, \mathrm{CD}^{+}{ }^{+}$, and $\mathrm{CD} 8^{+}$double-positive (DP) stage in which the IL-7R expresser is downregulated (Mombaerts et al. 1992; Shinkai et al. 1992; Shinkai and Alt 1994 and unpubl.). In this respect, precursor B cells in RAG-2-1- mice undergo similar phenotypic and functional alterations when complemented by expression of a functional $\mathrm{HC}$ (but not $\mathrm{LC}$ ) transgene. The large, $\mathrm{CD}^{-}{ }^{-}, \mathrm{c}-\mathrm{kit}^{+}, \mathrm{IL}-7-$ responsive, $\mathrm{sIg}^{-}$cells progress to a small, $\mathrm{CD}^{+}{ }^{+}, \mathrm{c}-\mathrm{kit}^{-}$, relatively IL-7 unresponsive cohort. Therefore, it appears that $\mathrm{B}$ and $\mathrm{T}$ cells share common strategies at this similar point in their development (for review, see Chen and Alt 1994). 
Expression of $\mu$ chains alters the $I L-7$ responsiveness of $B$-cell precursors

The lymphokine IL-7, which is produced by BM stromal cells, stimulates the proliferation but not differentiation of B-cell precursors in culture (Namen et al. 1988; Lee et al. 1989; Sherwood et al. 1990; Rolink et al. 1991a,b). After high-dose cyclophosphamide treatment, IL-7-supplemented mice reconstitute the peripheral B-cell population significantly faster than control animals (Morrissey et al. 1991). In another study treatment with antiIL-7 antibodies resulted in a severe depletion of the pre-B and B-cell compartments (Sudo et al. 1993). Together, these observations suggest that IL-7 may play a role in the population dynamics of the BM, where large losses of cells between the pro-B and pre-B compartments (for review, see Osmond 1990, 1991) reflect the stringent selection for a productive $\mathrm{HC}$ rearrangement.

Previous studies of normal BM demonstrated that the proliferative response to $\mathrm{IL}-7$ was enriched in the large $\left(0-40 \% \mu^{+}\right)$, rather than the small $\left(100 \% \mu^{+}\right)$, cells (Lee et al. 1989; Era et al. 1991). Studies of normal and immunoglobulin transgenic BM cells, using specific in vitro culture systems, have suggested, in addition, that a feature of the $\mu^{+}$developmental stage may be an ability to grow in the presence of IL-7 without stromal contacts (Era et al. 1991; Hardy et al. 1991; Reichman-Freid et al. 1993). In this context, we have found that BM cells expressing a $\mu \mathrm{HC}$ transgene have a decreased proliferative response to IL-7 compared with nontransgenic normal or RAG- $2^{-1-}$ controls. However, IL-7 supplementation is required for the in vitro culture of these cells, and BM cells in HC186 RAG-2 ${ }^{-1}$ mice still express the IL-7R $\alpha$ chain (F. Young and F. Alt, unpubl.). As the ligand for c-kit is the steel-encoded stem cell factor (for review, see Witte 1990), which has been reported to be costimulatory with IL-7 for both pre-B- and pre-T-cell growth (Murray et al. 1989; Rolink et al. 1991a; Godfrey et al. 1992, 1993; Palacios and Nishikawa 1992; Godfrey and Zlotnik 1993), down-regulation of c-kit expression on $\mu^{+}$pre-B cells may be related to the differential responsiveness of the $\mu^{+}$pre-B cells to IL-7. Although the precise mechanism remains to be elucidated, these data demonstrate that expression of the $\mu \mathrm{HC}$ in differentiating pro-B cells effects an important change in their response to IL-7.

Expression of $\mu$ chains is not detectable on $\mathrm{HC} 186$ $R A G-2^{-1-} B M$ cells

The $\lambda_{5}$ and $V_{\text {pre-B }}$ SLCs in association with truncated or complete $\mu$ molecules ( $\mu /$ SLC complex) can be expressed on the surface of transformed pre-B cell lines; this complex is thought to comprise a functional signal transducing unit (Misener et al. 1991; Tsubata et al. 1992). Studies of both human and mouse BM have identified a population in the BM that expresses SLC on the cell surface (Cherayil and Pillai 1991; Nishimoto et al. 1991); these cells were thought to be "late" pre-B cells /Cherayil and Pillai 1991) expressing high levels of intracellular $\mu$ (Las- soued et al. 1993|. However, in HC186 RAG-2 ${ }^{-1-}$ mice (either high or low copy number), where the BM cells are arrested at the pre-B cell stage and transgenic $\mu$ associates intracellularly with $\lambda_{5}$, we could not detect surface expression of $\mu$ chains. Recent studies have demonstrated a functional effect of cross-linking TCR CD3 components on DN thymocytes, even those in which the surface expression of these components was essentially undetectable by standard immunofluorescence or immunoprecipitation techniques (Levelt et al. 1993; Shinkai and Alt 1994). It remains to be determined whether similar $\mu /$ SLC complexes exist on the surface of pre-B cells that are undetectable by immunofluorescent analyses.

Several studies have demonstrated surface expression of a pre-B-cell receptor on the surface of transformed cell lines (Pillai and Baltimore 1987; Misener et al. 1991; Takemori et al. 1990; Tsubata et al. 1992; Karasuyama et al. 1993, Lassoued et al. 1993). In accord with these data, we can detect low levels of $\mu$ chains, but not associated SLCs (which are poorly labeled by this procedure when associated with $\mu$ chains) on the surface of BM-derived A-MuLV-transformed cell lines from HC186 RAG-2-1mice by surface iodination but not by fluorescent staining. This observation may be interpreted in two ways. First, surface expression of a $\mu$ /SLC complex on primary cells, in contrast to cell lines, may be quantitatively below the limits of detection by immunofluorescence or immunoprecipitation techniques. Alternatively, surface deposition of $\mu$ (perhaps together with SLC that is undetectable by our labeling procedures) in A-MuLV transformants may be a misleading phenomenon that reflects the inappropriate regulation of differentiation events in transformed cell lines (Schlissel et al. 1991).

Other recent reports provide information relevant to our current findings. In a PCR analysis of sorted BM fractions, the expression of $\lambda_{5}$ was found to be decreased 10 -fold in the small pre-B compartment when compared with the level of expression in pro-B cells (Li et al. 1993). These data are in accord with our observations that expression of $\lambda_{5}$ transcripts is decreased significantly in the $\mathrm{B}^{2} 20^{+}$cell population of of $\mathrm{HCl} 186 \mathrm{RAG}-2^{-/-}$mice as compared with RAG-2 $2^{-1-}$ controls. More importantly, monoclonal antibodies to $\lambda_{5}$ and $V_{\text {preB }}$ have been used to demonstrate $\lambda_{5}$ expression on normal and RAG-2-1pro-B cells (Karasuyama et al. 1994). In the same study, SLCs disappear from the surface of $\mathrm{B} 220^{+} \mathrm{BM}$ cells upon introduction of a $\mathrm{HC}$ transgene into the $\mathrm{RAG}-2^{-1-}$ background. Taken together, these data suggest that surface expression of surface $\lambda_{5} / V_{\text {preB }}$ complex occurs at the pro-B stage in the absence of $\mu$ chain expression and that $\mathrm{HC}$ expression leads to the down-regulation of $\lambda_{5}\left(\mathrm{~V}_{\mathrm{preB}}\right)$ expression, and the disappearance of this complex from the surface of the resulting pre-B-cell population (Karasuyama et al. 1994). In this context, $\lambda_{5}{ }^{-1}-$ mice have a defect in B-cell development that is manifested at the pro-B to pre-B transition (Kitamura et al. 1992; Rolink et al. 1993). Thus, it remains possible that the $\mu /$ SLC complex may be expressed in a functional, but transient, nature during the pro- $B$ to pre- $B$ transition, that the com- 
plex is expressed on the surface of pre-B cells at levels below detection by the procedures that we have used, or that the complex functions intracellularly at an early stage of differentiation. In any case, our current findings support the notion that speculated functions for the $\mu \mathrm{HC} / \mathrm{SLC}$ ("pre-B") receptor may require further evaluation (Karasuyama et al. 1994).

\section{Mitogen-responsive, IgM-secreting peripheral B cells in immunoglobulin-complemented $R A G-2^{-1-}$ mice}

The degree to which B-cell development and homing to secondary lymphoid organs may be dependent on cellular interactions with other B cells, on secreted products that reflect established B- or T-cell repertoires, or on the specificity of individual $\mathrm{V}$ regions (Vakil et al. 1986; Riggs et al. 1991; Carlsson et al. 1992; Coutinho 1993) remains controversial. The variable success in reconstitution of the B-cell compartment in immunoglobulin transgenic SCID mice has highlighted the importance of resolving these issues.

In the RAG- $2^{-1-}$ background, the expression of functionally assembled HC and LC genes leads to reconstitution of all BM compartments and to the development of a "monoclonal" peripheral B-cell compartment. As many of the mice analyzed are derived from RAG-2-deficient mothers, we can also unequivocally eliminate potential roles for maternal immunoglobulin or the function of multiple or specific (e.g., early expressed) immunoglobulin $\mathrm{HC}$ variable region genes as required for establishment of the the primary or peripheral B-cell pools. The fact that the $\lambda \mathrm{HCl} 86 \mathrm{RAG}-2^{-1-}$ mice produce serum immunoglobulin indicates that this monoclonal B-cell population is also naturally activated and can produce relatively physiological levels of serum immunoglobulin. In this context, preliminary experiments have indicated further the responsiveness of $\mathrm{RAG}-2^{-/-}$ peripheral B cells to T-cell signals and enhanced response to polyclonal activators in the presence of specific antigen (F. Young and F. Alt, unpubl.).

\section{Comparison of B-cell development in immunoglobulin transgene-complemented SCID and RAG-2-'- mice}

Introduction of $\mathrm{HC}$ transgenes into the SCID background leads to the development of a cell population with pre-B characteristics (Reichman-Fried et al. 1990, 1993); however, it has not been possible to consistently generate peripheral B-cell populations in SCID mice via introduction of immunoglobulin $\mathrm{HC}$ and $\mathrm{LC}$ transgenes (Reichman-Freid et al. 1990; F. Young, R. Phillips, F. Alt, unpubl.). It is possible to rationalize these findings based on considerations analogous to those considered previously for the relative ability of TCR $\beta$ or TCR $\alpha$ plus $\beta$ transgenes to rescue thymocyte and peripheral T-cell development in SCID versus RAG-deficient mice (Scott et al. 1989; Kishi et al. 1991; Mombaerts et al. 1992; Shinkai et al. 1992). Thus, it seems likely that HC/LC SCID mice still go through a stage in which rearrangements at either the HC or LC loci occur and which are lethal because of unrepaired double-strand breaks (Bosma and Carroll 1991). Because RAG-2-deficient mice do not initiate such rearrangements, B-cell development may occur more efficiently in the double transgenic RAG-2 ${ }^{-1-}$ animal.

An interesting issue is why both HC SCID (ReichmanFried et al. 1990, 1993) and HC RAG-2 ${ }^{-1-}$ (this study) appear to generate relatively normal numbers of pre-B cells, a stage in which LC rearrangements should normally occur. In the RAG-2 ${ }^{-1-}$ animals, cells do not initiate double-strand breaks and are therefore able to accumulate. In comparison, accumulation of pre-B cells in $\mathrm{HC} / \mathrm{SCID}$ mice may suggest that although cells in this population may initiate double-strand breaks at LC (or $\mathrm{HC}$ loci, they may be relatively immune to the adverse effects of such breaks because this is a relatively nondividing population and/or cells have a short life span. Perhaps only upon further differentiation (in the context of HC plus LC transgene expression) and expansion do accumulated double-strand breaks lead to cell death, and block accumulation of peripheral B cells in these animals.

\section{Materials and methods}

Construction of immunoglobulin expression vectors

The $\mathrm{HC} 186$ vector was constructed by subcloning a $30-\mathrm{kb}$ SalI fragment containing the murine $\mu \delta$ locus (a gift of C.C. Goodnow, Stanford University, CA) and a 4.5-kb EcoRI fragment containing VH186.2/DFL16/JH2/E $\mu$ from the vector pSV $\mu$ M5 (a gift from $M$. Reth, Max Planck Institute, Freiburg, Germany) into pBluescript SK II (Stratagene, La Jolla, CA). The LC transgene was constructed by subcloning a $7.4-\mathrm{kb}$ EcoRI fragment of Ig303 (Bernard et al. 1978) and the Xba-EcoRI fragment of pSV $\mu$ M5 containing the $\mathrm{E} \mu$ element into pBluescript. Two point mutations at amino acid positions 25 and 32 in the LC transgene were eliminated by subcloning a 500-bp EcoRI-KpnI fragment from a $\lambda_{2}$ transgene that is unmutated and has $100 \%$ homology to $\lambda_{1}$ in this portion of the $\lambda_{1}$ gene (Bernard et al. 1978; Blackwell et al. 1986). The $J_{\mathrm{H}}$ probe (Chen et al. 1993) and the $V_{\lambda}$ (Blackwell et al. 1986) probe were reported previously.

\section{Generation of transgenic mice}

The BssHII fragment containing the HC construct and the PvuII fragment containing the LC construct were microinjected into fertilized oocytes using standard methods (Hogan et al. 1986). Transgenic progeny were identified by Southern analysis of tail tip DNA and crossed into the RAG-2 ${ }^{-1-}$ background.

\section{Flow cytometry analysis}

Single-cell suspensions were stained by standard methods (Parks et al. 1986), and reactivity of specific antibodies with cells in the lymphocyte gate were analyzed on FACScan (Becton Dickinson, Mountain View, CA) with LYSYS (Fig. 2) or C-30 (Fig. 3) software. Antibodies purchased from PharMingen (San Diego, CA): fluorescein-conjugated (fl) RA3-6B2 (B220/CD45R), CD43 (S7), R5-240 (k), and AMS 9.1 (IgD ${ }^{\text {a }}$ Fig. 7) phycoerythrin (PE)-conjugated 3009-91 ( $\lambda$ ), RM2-5 (CD2), DS-1 (IgMª , Fig. 7), biotin-conjugated (bi) R6-60.2 (IgM). Biotinylated anti-c-kit (ACK4) was a gift of S.-I. Nishikawa (Kyoto University, Japan). The anti-idiotype AC38 (HC+LC specific) was a gift of K. Ra- 
jewsky (Institut für Genetik, Cologne, Germany). Biotinylated reagents were revealed with streptavidin-PE (Pharmingen).

\section{Generation of A-MuLV lines, lymphoid cell culture, and analysis}

A-MuLV-transformed pre-B cell lines were established as described previously (Rosenberg et al. 1975).

Lymphoid cultures were established as described (Morrow et al. 1992). Lymphoid growth from HC transgenic BM controls could be established in the presence of $200 \mathrm{U} / \mathrm{ml}$ of recombinant human IL-7 (a gift from S. Gillis, Immunex, Seattle, WA), with the following modifications: Cells were plated in $6-\mathrm{cm}$ plates at a density of $3 \times 10^{6}$ to $5 \times 10^{6} / \mathrm{ml}$. One-half of the media was changed 3 days after plating, and every 4-5 days after significant lymphoid growth was observed, taking care not to disturb the nonadherent cells. For in vitro growth analysis, BM cells from $\mathrm{HCl}$ 86L transgenic mice (either RAG-2 ${ }^{-1-}$ or RAG$2^{+1-}$ ) and controls was plated (in the absence of IL-7) at $2 \times 10^{6}$ / $\mathrm{ml}$ in $6-\mathrm{cm}$ plates. The media were changed after 3 days, and every 3 days thereafter, until a confluent layer of stromal cells was observed. Parallel cultures of BM were established in the presence of IL-7, as detailed above. When healthy stromal layers were near confluence (usually 6-10 days after plating) the plates were washed three times with PBS, and the cells were mitotically inactivated (mitomycin-C). After an overnight incubation to monitor the health of the feeder layer, nonadherent cells from BM cultures were harvested, counted, and plated on the genotypically matched feeder plates in the presence of IL-7. Cell viability was monitored daily by trypan blue exclusion, and nonadherent cells were resuspended thoroughly before counting. BM proliferation in response to IL-7 was assessed by incorporation of $\left[{ }^{3} \mathrm{H}\right]$ thymidine as described (Lee et al. 1989), except that proliferation was assayed after 5 days. LPS responsiveness of peripheral B cells was measured as described (Chen et al. 1993) using $10 \mu \mathrm{g} / \mathrm{ml}$ of lipopolysaccharide.

\section{Biochemical and protein analysis}

The metabolic labeling of cells with $\left[{ }^{35} \mathrm{~S}\right]$-methionine/cysteine (Amersham biochemicals), preparation of cell lysates, surface labeling with ${ }^{125}$ I (New England Nuclear), immunoprecipitations, and one-dimensional SDS-PAGE were performed as described previously (Ardman et al. 1990), with the following modifications: $\left[{ }^{35} \mathrm{~S}\right]$ methionine/cysteine-labeled lysates were precleared with Sepharose $4 \mathrm{~B}$ coupled to BSA for $2 \mathrm{hr}$, and all SDS-PAGE analyses were done using $15 \%$ final acrylamide concentration, with a cross-linker/acrylamide ratio $(\% \mathrm{C})$ of 1.7 . The nonreducing/reducing two-dimensional SDS-PAGE analysis was $15 \%$ polyacrylamide in both dimensions $(1.7 \% \mathrm{C})$, and visualized by fluorography. Experiments using primary BM cells were performed on lymphocytes flushed from the femurs and humeruses of 3-week-old mice; mononuclear cells were harvested from the interface after Ficoll centrifugation, washed twice with PBS, and resuspended in the appropriate labeling media. The polyclonal goat anti- $\mu$ antibody and the cross-reactive goat anti- $\lambda$ antibody, which also recognizes the $\lambda_{5}$ SLC (Tsubata et al. 1992), was purchased from Southern Biotechnology (Birmingham, AL). The anti-tubulin antibody was a gift from L. Cantley, Beth Israel Hospital, Boston, MA.

\section{Northern analyses}

Approximately $12 \mu \mathrm{g}$ of total RNA was fractionated on $1 \%$ formaldehyde-agarose gels, transferred to nylon membrane, and hybridized with the appropriate probes. The $\lambda_{5}$ probe is a $0.6-\mathrm{kb}$
R1 fragment from a subtracted pre-B-cell cDNA library. (Yancopoulos et al. 1990). The MB-1 probe was a gift from M. Reth (Freiburg, Germany). The $\mathrm{K}^{\circ}$ probe is a 0.9-kb EcoRI fragment that contains the initiation site of the $8.4-\mathrm{kb}$ germ-line $\kappa$ transcript (Van Ness et al. 1981). Hybridizing bands were visualized and analyzed using PhosphoImager technology. (Molecular Dynamics.)

\section{ELISAS}

Immulon 1 plates (Dynatech) were coated with $5 \mu \mathrm{g} / \mathrm{ml}$ of rabbit anti- $\mu$ antibody, incubated with serum dilutions, and revealed with either alkaline phosphatase labeled secondary antibody, or biotinylated anti-idiotype followed by akaline phosphatase-labeled streptavidin. The percent of idiotype-positive IgM was determined by comparing the anti-IgM reactivity remaining in a serum sample of known initial concentration following incubation with an excess of immobilized anti-idiotype.

\section{Acknowledgments}

This paper is dedicated to Dr. Sheldon M. Wolff. We thank Jianzhu Chen for reviewing the manuscript, Andrea Bottaro for advice, and Valerie Stewart, Laurie Davidson, and Deb Ahern for technical assistance. This work was supported by the Howard Hughes Medical Institute and by National Institute of Health grants AI20047, CA42335, and U01 AI31541: to F.W.A., and grant AI33180 to B.A. F.Y. was supported by a fellowship from the Robert Wood Johnson Foundation. Y.S. is supported by an Arthritis Investigator Award and a Leukemia Society of America Special Fellowship. The Basel Institute for Immunology was founded and is supported by F. Hoffmann-La Roche Limited Company, Basel, Switzerland.

The publication costs of this article were defrayed in part by payment of page charges. This article must therefore be hereby marked "advertisement" in accordance with 18 USC section 1734 solely to indicate this fact.

\section{References}

Albert-Wolf, M.S. Meuer, and R. Wallich. 1991. Dual function of recombinant human CD58: Inhibition of T cell adhesion and activation via the CD2 pathway. Int. Immunol. 3: 13351341.

Allman, D.M., S. Ferguson, and M. Cancro. 1992. Peripheral B cell maturation I. Immature peripheral $B$ cells in adults are Heat-Stable Antigen ${ }^{\text {hi }}$ and exhibit unique signaling characteristics. I. Immunol. 149: 2533-2540.

Alt, F.W., T.K. Blackwell, and G. Yancopoulos. 1987. Development of the primary antibody repertoire. Science 238: 10791087.

Ardman, B., M.A. Sikorski, M. Settles, and D.E. Staunton. 1990. Human immunodeficiency virus type 1 -infected individuals make autoantibodies that bind to CD43 on normal thymic lymphocytes. J. Exp. Med. 172: 1151-1158

Bernard, O., N. Hozumi, and S. Tonegawa. 1978. Sequences of mouse immunoglobulin light chain genes before and after somatic changes. Cell 15: 1133-1144.

Biedermann, K., J. Sunk, A. Giaccia, L. Tosto, and M. Brown. 1991. SCID mutation in mice confers hypersensitivity to ionizing radiation and a deficiency in DNA double-strand break repair. Proc. Natl. Acad. Sci. 88: 1394-1397.

Blackwell, T.K., M. Moore, G. Yancopoulos, H. Suh, S. Lutzker, E. Selsing, and F.W. Alt. 1986. Recombination between immunoglobulin variable region gene segments is enhanced by transcription. Nature 324: 585-589. 
Blackwell, T.K., B. Malynn, R. Pollock, P. Ferrier, L. Covey, G. Fulop, R. Phillips, G. Yancopoulos, and F.W. Alt. 1989. Isolation of SCID pre-B-cells that rearrange kappa light chain genes: Formation of normal signal and abnormal coding joins. $E M B O$ J. 8: 735-742.

Bosma, M.J. and A.M. Carroll. 1991. The SCID mouse mutant: Definition, characterization, and potential uses. Annu. Rev. Immunol. 9: 323-350.

Carlsson, L., C. Overmo, and D. Holmberg. 1992. Developmentally controlled selection of antibody genes: Characterization of individual VH7183 genes and evidence for stage-specific somatic diversification. Eur. J. Immunol. 22: 71-78.

Chen, J., Y. Shinkai, F. Young, and F.W. Alt. 1994. Probing immune functions in RAG-deficient mice. Curr. Opin. Immunol. 6: 313-319.

Chen, J., M. Trounstine, F.W. Alt, F. Young, C. Kurahara, J. Loring, and D. Huszar. 1993. Immunoglobulin gene rearrangment in $\mathrm{B}$ cell deficient mice generated by targeted deletion of the $\mathrm{J}_{\mathrm{H}}$ locus. Int. Immunol. 5: 647-656.

Cherayil, B.J. and S. Pillai. 1991. The $\omega / \lambda 5$ surrogate immunoglobulin light-chain is expressed on the surface of transitional B lymphocytes in murine bone marrow. I. Exp. Med. 173: $111-116$.

Clark, E. and J. Ledbetter. 1994. How B and T cells talk to each other. Nature 367: 425-428.

Coffman, R.L. and I.L. Weissman. 1983. Immunoglobulin gene rearrangement during pre-B cell differentiation. J. Mol. Cell. Immunol. 1: 31-41.

Coutinho, A. 1993. Lymphocyte survival and V-region selection. Immunol. Today 14: 38-41.

Ehlich, A., S. Schaal, H. Gu, D. Kitamura, W. Müller, and K. Rajewsky. 1993. Immunoglobulin heavy and light chain genes rearrange independently at early stages of B cell development. Cell 72: 695-704.

Era, T., M. Ogawa, S. Nishikawa, M. Okamoto, T. Honjo, K. Akagi, J. Miyazaki, and K. Yamamura. 1991. Differentiation of growth signal requirement of $\mathrm{B}$ lymphocyte precursor is directed by expression of immunoglobulin. EMBO $T$. 10: 337-342.

Fulop, G.M. and R.A. Phillips. 1990. The SCID mutation in mice causes a general defect in DNA repair. Nature 347: $479-482$.

Godfrey, D.I., A. Zlotnik, and T. Suda. 1992. Phenotypic and functional characterization of c-kit expression during intrathymic T cell development. J. Immunol. 149: 2281-2285.

Godfrey, D.I., J. Kennedy, T. Suda, and A. Zlotnik. 1993. A developmental pathway involving four phenotypically and functionally distinct subsets of $\mathrm{CD} 3^{-} \mathrm{CD} 4^{-} \mathrm{CD} 8^{-}$triplenegative adult mouse thymocytes defined by CD44 and CD25 expression. I. Immunol. 150: 4244-4252.

Godfrey, D.I. and A. Zlotnik. 1993. Control points in early T-cell development. Immunol. Today 14: 547-553.

Goodnow, C.C., J Crosbie, S. Adelstein, T. Lavoie, S. SmithGill, R. Brink, H. Pritchard-Briscoe, J. Wotherspoon, R. Loblay, K. Raphael, R. Trent, and A. Basten. 1988. Altered immunoglobulin expression and functional silencing of selfreactive $B$ lymphocytes in transgenic mice. Nature 334: 676-682.

Hardy, R.R., C.E. Carmack, S.A. Shinton, J.D. Kemp, and K. Hayakawa. 1991. Resolution and characterization of pro-B and pre-pro-B cell stages in normal mouse bone marrow. $J$. Exp. Med. 173: 1213-1225.

Hendrickson, E.A., S. Qin, E.A. Bump, D.G. Schatz, M. Oettinger, and D.T. Weaver. 1990. A link between double-strand break-related repair and $V(D) /$ recombination: The scid mutation. Mol. Cell Biol. 10: 5397-5407.
Hogan, B., F. Costantini, and E. Lacy. 1986. Manipulation of the mouse embryo: A laboratory manual. Cold Spring Harbor Laboratory Press, Cold Spring Harbor, New York.

Iglesias, A., M. Kopf, G.F. Williams, B. Buhler, and G. Kohler. 1991. Molecular requirements for the $\mathrm{m}$-induced light chain gene rearrangement in pre-B cells. $E M B O J$. 10: 2147-2156.

Justement, L., K. Campbell, N. Chien, and J. Cambier. 1991. Regulation of B cell antigen receptor signal transduction and phosphorylation by CD45. Science 252: 1839-1842.

Karasuyama, H., A. Kudo, and F. Melchers. 1990. The proteins encoded by the $V_{\text {preB }}$ and $\lambda_{5}$ pre-B cell specific genes can associate with each other and with $\mu$ heavy-chain. I. Exp. Med. 172: 969-972

Karasuyama, H., A. Rolink, and F. Melchers. 1993. A complex of glycoproteins is associated with $\mathrm{V}_{\text {pre- } \mathrm{B}} / \lambda_{5}$ surrogate light chain on the surface of $\mu$ heavy chain-negative early precursor B cell lines. J. Exp. Med. 178: 469-478.

Karasuyama, H., A. Rolink, Y. Shinkai, F. Young, F.W. Alt, and F. Melchers. 1994. The expression of $\mathrm{V}_{\text {pre-B }} / \lambda_{5}$ surrogate light chain in early bone marrow precursor $B$ cells of normal and B cell-deficient mutant mice. Cell 77: 133-143.

Kerr, W.G., M. Cooper, L. Feng, P. Burrows, and L.M. Hendershot. 1989. Mu heavy chains can associate with a pseudolight chain complex $(\pi \mathrm{L})$ in human pre-B cell lines. Int. Immunol. 1: 355-361.

Kishi, H., P. Borgulya, B. Scott, K. Karjalainen, A. Traunecher, J. Kaufman, and $H$. von Boehmer. 1991. Surface expression of the $\beta$ T cell receptor (TCR) chain in the absence of other TCR or CD3 proteins on immature T cells. EMBO J. 10: 93-100.

Kishihara, K., J. Penninger, V.A. Wallace, T.M. Kündig, K. Kawai, A. Wakeman, E. Timms, K. Pfeffer, P.S. Ohashi, M.L. Thomas, C. Furlonger, C.J. Paige, and T.W. Mak. 1993. Normal B lymphocyte development but impaired $\mathrm{T}$ cell maturation in CD45-exon 6 protein tyrosine phosphatase-deficient mice. Cell 74: 143-156.

Kitamura, D. and K. Rajewsky. 1992. Targeted disruption of $\mu$ chain causes loss of heavy chain allelic exclusion. Nature 356: 154-156.

Kitamura, D., J. Roes, R. Kuhn, and K. Rajewsky. 1991. A B-cell deficient mouse by targeted disruption of the membrane exon of the immunoglobulin $\mu$ chain gene. Nature 350: 423426.

Kitamura, D., A. Kudo, S. Schaal, W. Muller, F. Melchers, and K. Rajewsky. 1992. A critical role of $\lambda 5$ in B cell development. Cell 69: 823-831.

Koretzky, G.A., J. Picus, T. Schultz, and A. Weiss. 1991. Tyrosine phosphatase CD45 is required for T-cell antigen receptor and CD2-mediated activation of a protein tyrosine kinase and interleukin 2 receptor. Proc. Natl. Acad. Sci. 88: 20372041.

Lassoued, K., C.A. Nunez, L. Billips, H. Kubagawa, R.C. Monteiro, T.W. LeBien, and M.D. Cooper. 1993. Expression of surrogate light chain receptors is restricted to a late stage in pre-B cell differentiation. Cell 73: 73-86.

Lee, G., A.E. Namen, S. Gillis, L.R. Ellingsworth, and P.W. Kinkade. 1989. Normal B cell precursors responsive to recombinant murine IL-7 and inhibition of IL-7 activity by transforming growth factor- $\beta 1$. I. Immunol. 142: 3875-3883.

Lennon, G.G. and R.P. Perry. 1990. The temporal order of appearance of transcripts from unrearranged and rearrangend Ig genes in murine fetal liver. I. Immunol. 144: 1983-1987.

Levelt, C.N., P. Mombaerts, A. Iglesias, S. Tonegawa, and K. Eichmann. 1993. Restoration of early thymocyte differentiation in $\mathrm{T}$ cell receptor- $\beta$ chain deficient mutant mice by transmembrane signaling through CD3€. Proc. Natl. Acad. Sci. 90: 11401-11405. 
Li, Y.-S., K. Hayakawa, and R.R. Hardy. 1993. The regulated expression of $\mathrm{B}$ lineage associated genes during $\mathrm{B}$ cell differentiation in bone marrow and fetal liver. I. Exp. Med. 178: 951-960.

Lieber, M.R., J. Hesse, S. Lewis, G. Bosma, N. Rosenberg, K. Mizuchi, M. Bosma, and M. Gellert. 1988. The defect in murine severe combined immune deficiency; joining of signal sequences but not coding segments in V(D)J recombination. Cell 55: 7-16.

Malynn, B.A., T.K. Blackwell, G. Fulop, G. Rathbun, A. Furley, P. Ferrier, B. Heinke, R. Phillips, G. Yancopoulos, and F.W. Alt. 1988. The SCID defect affects the final step of the immunoglobulin VDJ recombinase mechanism. Cell 54: 453460.

Melchers, F., H. Karasuyama, D. Haasner, S. Bauer, A. Kudo, N. Sakaguchi, B. Jameson, and A. Rolink. 1993. The surrogate light chain in B cell development. Immunol. Today 14: 6068.

Misener, V., G.P. Downey, and J. Jongstra. 1991. The immunoglobulin light chain related protein $\lambda_{5}$ is expressed on the surface of mouse pre-B cell lines and can function as a signal transducing molecule. Int. Immunol. 3: 1129-1136.

Mombaerts, P., A. Clarke, M. Rudnicki, J. Iacomini, S. Itohara, J. Lafaille, L. Wang, Y. Ichikawa, R. Jaenisch, M. Hooper, and S. Tonegawa. 1992. Mutations in T-cell antigen receptor genes $\alpha$ and $\beta$ block thymocyte development at different stages. Nature 360: 225-231.

Morrissey, P.J., P. Conlon, S. Braddy, D.E. Williams, A.E. Namen, and D.Y. Mochizuki. 1991. Administration of IL-7 to mice with cyclophosphamide-induced lymphopenia accelerates lymphocyte repopulation. J. Immunol. 146: 1547-1552.

Morrow, M., G. Lee, S. Gillis, G. Yancopoulos, and F.W. Alt. 1992. Interleukin-7 induces $\mathrm{N}-m y c$ and $\mathrm{c}-m y c$ expression in normal precursor lymphocytes. Genes \& Dev. 6: 61-70.

Murray, R., T. Suda, N. Wrighton, F. Lee, and A. Zlotnik. 1989. IL-7 is a growth and maintenance factor for mature and immature thymocyte subsets. Int. Immunol. 1: 526-531.

Namen, A.E., S. Lupton, K. Hjerrild, J. Wignall, D. Mochizuki, A. Schmierer, B. Mosley, C. March, D. Urdal, S. Gillis, D. Cosman, and R. Goodwin. 1988. Stimulation of B-cell progenitors by cloned murine interleukin-7. Nature 333: $571-$ 573.

Nishimoto, N., H. Kubagawa, T. Ohno, G.L. Gartland, A.K. Stankovic, and M.D. Cooper. 1991. Normal pre-B cells express a receptor complex of $\mu$ heavy chains and surrogate light chain proteins. Proc. Natl. Acad. Sci. 88: 6284-6288.

Osmond, D.G. 1990. B cell development in the bone marrow. Sem. Immunol. 2: 173-180.

. 1991. Proliferation kinetics and the lifespan of B cells in central and peripheral lymphoid organs. Curr. Opin. Immunol. 3: 179-185.

Palacios, R. and S.I. Nishikawa. 1992. Developmentally regulated cell surface expression and function of $\mathrm{c}-\mathrm{kit}$ receptor during lymphocyte ontogeny in the embryo of adult mice. Development 115: 1133-1147.

Parks, D.R., L. Lanier, and L.A. Herzenberg. 1986. Flow cytometry and fluorescence activated cell sorting (FACS). In Handbook of experimental immunology (ed/ D.M. Weir, L.A. Herzenberg, C.C. Blackwell, and L.A. Herzenberg) pp. 29.129.21. Blackwell Scientific, London, UK.

Pillai, S. and D. Baltimore. 1987. Formation of disulphide-linked $\mu_{2} \omega_{2}$ tetramers in pre-B cells by the $18 \mathrm{~K} \omega$-immunoglobulin light chain. Nature 329: 172-174.

Pingel, J.T. and M.L. Thomas. 1989. Evidence that the leukocyte-common antigen is required for antigen-induced $T$ lymphocyte proliferation. Cell 58: 1055-1065.
Rajewsky, K. 1992. Early and late B-cell development in the mouse. Curr. Opin. Immunol. 4: 171-176.

Reichman-Fried, M., R. Hardy, and M. Bosma. 1990. Development of B-lineage cells in the bone marrow of SCID mice following the introduction of functionally rearranged immunoglobulin transgenes. Proc. Natl. Acad. Sci. 87: 2730-2739.

Reichman-Fried, M., M.J. Bosma, and R.R. Hardy. 1993. B-lineage cells in $\mu$-transgenic scid mice proliferate in response to IL- 7 but fail to show evidence of immunoglobulin light chain gene rearrangement. Int. Immunol. 5: 303-310.

Reth, M., T. Imanishi-Kari, and K. Rajewsky. 1979. Analysis of the repertoire of anti-(4-hydroxy-3-nitro-phenyl) acetyl (NP) antibodies in C57BL/6 mice by cell fusion. II. Characterization of idiotopes by monoclonal anti-idiotope antibodies. Eur. J. Immunol. 9: 1004-1013.

Reth, M., P. Ammirati, S. Jackson, and F.W. Alt. 1985. Regulated progression of a cultured pre-B-cell line to the B-cell stage. Nature 317: 353-355.

Riggs I., R. Stowers, and D. Mosier. 1991. Adoptive transfer of neonatal $\mathrm{T}$ lymphocytes rescues immunoglobulin production in mice with severe combined immune deficiency. $J$. Exp. Med. 173: 265-268.

Rolink, A. and F. Melchers. 1991. Molecular and cellular origins of B lymphocyte diversity. Cell 66: 1081-1094.

- 1993. Generation and regeneration of cells of the B-lymphocyte lineage. Curr. Opin. Immunol. 5: 207-217.

Rolink, A., M. Streb, S.I. Nishikawa, and F. Melchers. 1991a. The c-kit encoded tyrosine kinase regulates the proliferation of early pre-B cells. Eur. J. Immunol. 21: 2609-2612.

Rolink, A., A. Kudo, H. Karasuyama, Y. Kikuchi, and F. Melchers. 1991b. Long-term proliferation of early pre-B cell lines and clones with the potential to develop to surface Ig-positive, mitogen reactive $B$ cells in-vitro and in-vivo. EMBO I. 10: 327-336.

Rolink, A., H. Karasuyama, U. Grawunder, D. Hassner, A. Kudo, and F. Melchers. 1993. B cell development in mice with a defective $\lambda_{5}$ gene. Eur. I. Immunol. 23: 1284-1288.

Rosenberg, N., D. Baltimore, and C.D. Scher. 1975. In vitro transformation of lymphoid cells by Abelson murine leukemia virus. Proc. Nat1. Acad. Sci. 72: 1932-1936.

Sakaguchi, N., S. Kashiwamura, M. Kimoto, P. Thalmann, and F. Melchers. 1988. B lymphocyte lineage-restricted expression of $m b-1$, a gene with CD3-like structural properties. $E M B O$ I. 7: 3457-3464.

Schlissel, M.S. and D. Baltimore. 1989. Activation of immunoglobulin kappa gene rearrangement correlates with induction of germline kappa gene transcription. Cell 58: 10011007.

Schlissel, M.S., L.M. Corcoran, and D. Baltimore. 1991. Virustransformed pre-B cells show ordered activation but not inactivation of immunoglobulin gene rearrangement and transcription. J. Exp. Med. 173: 711-720.

Schraven, B., Y. Samstag, P. Altevogt, and S.C. Meuer. 1990. Association of CD2 and CD45 on human T lymphocytes. Nature 345: 71-74.

Scott B., H. Bluthmann, H.S. Teh, and H. von Boehmer. 1989. Generation of mature T cells requires interaction of the $\alpha \beta \mathrm{T}$ cell receptor with major histocompatibility antigens. Nature 338: 591-593.

Sen, J., N. Rosenberg, and S. Burakoff. 1990. Expression and ontogeny of CD2 on murine B cells. J. Immunol. 144: 29252930.

Sherwood, P.J. and I.L. Weissman. 1990. The growth factor IL-7 induces expression of a transformation-associated antigen in normal pre-B cells. Int. Immunol. 2: 399-406.

Shinkai, Y., G. Rathbun, K.-P. Lam, E.M. Oltz, V. Stewart, M. 
Mendelsohn, J. Charron, M. Datta, F. Young, A.M. Stall, and F.W. Alt. 1992. RAG-2 deficient mice lack mature lymphocytes owing to inability to initiate V(D)| rerrangement. Cell 68: $855-867$.

Shinkai, Y., S. Koyasu, K.-I. Nakayama, K.M. Murphy, D.Y. Loh, E.L. Reinherz, and F.W. Alt. 1993. Restoration of T-cell development in RAG-2 deficient mice by functional TCR transgenes. Science 259: 822-825.

Shinkai, Y. and F.W. Alt. 1994. CD3e mediated signals rescue the development of CD4 $+8+$ thymocytes in the absence of TCR $\beta$ chain expression. Int. Immunol. (in press).

Siden, E., F. Alt, L. Shinefeld, V. Sato, and D. Baltimore. 1981. Synthesis of immunoglobulin $\mu$ chain gene products precedes synthesis of light chains during B lymphocyte development. Proc. Natl. Acad. Sci. 78: 1823-1827.

Springer, T., M. Dustin, T. Kishimoto, and S. Marlin. 1987. The lymphocyte function-associated LFA-1, CD2, and LFA-3 molecules: Cell adhesion receptors of the immune system. Annu. Rev. Immunol. 5: 223-252.

Sudo, T., S. Nishikawa, N. Ohno, N. Akiyama, M. Tamakoshi, H. Yoshida, and S.-I. Nishikawa. 1993. Expression and function of the interleukin 7 receptor in murine lymphocytes. Proc. Natl. Acad. Sci. 90: 9125-9129.

Takemori, T., J. Mizuguchi, I. Miyazoe, M. Nakanishi, K. Shigemoto, H. Kimoto, T. Shirasawa, N. Maruyama, and M. Taniguchi. 1990. Two types of $\mu$ complexes are expressed during differentiation from pre-B to mature B cells. EMBO $I$. 9: 2493-2500.

Tsubata, T. and M. Reth. 1990. The products of the pre-B cellspecific genes $\left(\lambda_{5}\right.$ and $\left.V_{\text {pre-B }}\right)$ and the immunoglobulin $\mu$ chain form a complex that is transported onto the cell surface. J. Exp. Med. 172: 973-976.

Tsubata, T., R. Tsubata, and M. Reth. 1992. Crosslinking of the cell surface immunoglobulin $(\mu$-surrogate light chain complex) on pre-B cells induces activation of $V$ gene rearrangements at the immunoglobulin $\kappa$ locus. Int. Immunol. 4: 637-641.

Vakil, M., H. Sauter, C. Paige, and J.F. Kearney. 1986. In vivo suppression of perinatal multispecific $B$ cells results in a distortion of the adult B cell repertoire. Eur. I. Immunol. 16: 1159-1165.

Van Ness, B.G., M. Weigert, C. Coleclough, E. Mather, D. Kelley, and R. Perry. 1981. Transcription of the unrearranged mouse $C_{\kappa}$ locus: Sequence of the initiation region and comparison of activity with a rearranged $\mathrm{V}_{\kappa}-\mathrm{C}_{\kappa}$ gene. Cell 27: 593-602.

Whitlock, C.A. and O. Witte. 1982. Long-term culture of B lymphocytes and their precursors from murine bone marrow. Proc. Natl. Acad. Sci. 79: 3608-3612.

Witte, O. 1990. Steel locus defines new multipotent growth factor. Cell 63: 5-6.

Yagita, H., T. Nakamura, H. Karasuyama, and K. Okumura. 1989. Monoclonal antibodies specific for murine CD2 reveal its presence on B cells as well as T cells. Proc. Natl Acad. Sci. 86: 645-651.

Yancopoulos, G., E. Oltz, G. Rathbun, J. Berman, R. Smith, R. Lansford, P. Rothman, A. Okada, G. Lee, M. Morrow, K. Kaplan, S. Prockop, and F.W. Alt. 1990. Isolation of coordinately regulated genes that are expressed in discrete stages of B cell development. Proc. Natl. Acad. Sci. 87: 5759-5763. 


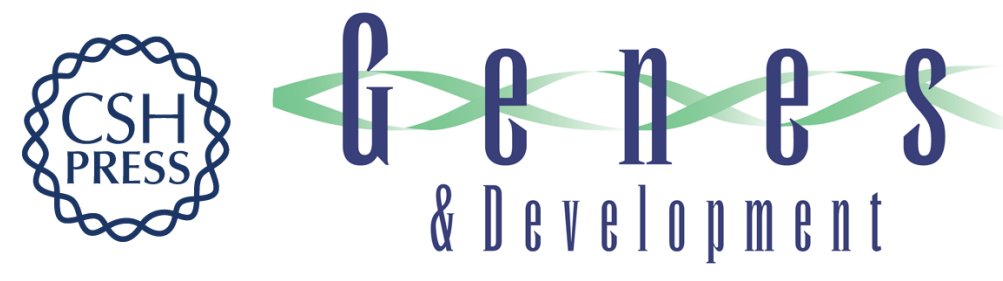

\section{Influence of immunoglobulin heavy- and light-chain expression on B-cell differentiation.}

F Young, B Ardman, Y Shinkai, et al.

Genes Dev. 1994, 8:

Access the most recent version at doi:10.1101/gad.8.9.1043

References This article cites 90 articles, 33 of which can be accessed free at: http://genesdev.cshlp.org/content/8/9/1043.full.htmI\#ref-list-1

License

Email Alerting

Receive free email alerts when new articles cite this article - sign up in the box at the top Service right corner of the article or click here.

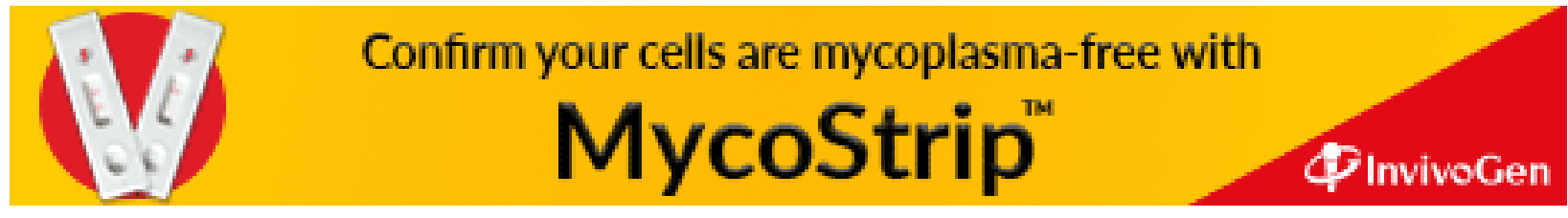

